Primljeno: 8.4.2019.

Prihvaćeno: 3.5.2019.

DOI: https://doi.org/10.36506/av.62.1

\author{
Nenad Bukvić \\ Hrvatski državni arhiv \\ Zagreb, Hrvatska \\ nbukvic@arhiv.hr
}

\title{
FINANCIRANJE DRŽAVNIH ARHIVA KROZ PROGRAME JAVNIH POTREBA U KULTURI REPUBLIKE HRVATSKE
}

\author{
UDK: 336.1 \\ 008 \\ 930.25:336 (497.5)
}

Pregledni rad

U članku su prezentirani rezultati analize financiranja državnih arhiva proračunskim sredstvima namijenjenim financiranju javnih potreba u kulturi Republike Hrvatske u posljednjem desetogodisnjem razdoblju. Dane su nove spoznaje o financiranju arhivâ, śto se uobičajeno navodi među ključnim čimbenicima (uz prostorne $i$ ljudske resurse) koji utječu na stanje arhivske službe u Hrvatskoj. Rezultati analize sistematizirani su u obliku grafikona i tabličnih prikaza. Interpretirani su u sirem kontekstu kretanja relativnoga udjela Ministarstva kulture u državnom proračunu Republike Hrvatske te ulaganja u programe drugih kulturnih djelatnosti. Izmecu ostaloga, rezultati pokazuju vrstu, opseg $i$ kontinuitet aktivnosti na koje su arhivi $u$ sustavu javne arhivske službe stavljali naglasak, te njihovu podudarnost s osnovnim zadaćama arhivâ. Zajedno s pregledom kretanja iznosa odobrenih sredstava, takvi su podatci i jedan od pokazatelja odnosa države prema arhivskoj djelatnosti. Mogućnost praktične primjene rezultata istraživanja je u tome što daju podlogu za preispitivanje pristupa državnih arhiva u planiranju arhivskih programa, kao i metodologije financiranja od strane mjerodavnoga ministarstva.

Ključne riječi: arhivi; arhivski programi; arhivska služba; financiranje; kulturne djelatnosti; kulturna politika; programi javnih potreba u kulturi; Ministarstvo kulture 


\section{Uvod}

U stručnim raspravama o stanju arhivske službe u Hrvatskoj, među ključnim čimbenicima koji ju određuju i uvjetuju u pravilu se navodi i njezino financiranje. Unatoč tomu, u dosadašnjoj domaćoj arhivističkoj literaturi ta tema nije zastupljena u većem opsegu. Njezin istraživački potencijal očituje se u velikom broju podtema koje je moguće obrađivati (primjerice financiranje arhivske djelatnosti u odnosu na ostale djelatnosti u kulturi, financiranje pojedinih segmenata arhivske djelatnosti, analiza prema pojedinačnim izvorima financiranja). Očituje se i u pristupu temi, odnosno podtemama koji može biti takav da ne mora nužno imati praktičnu primjenu ili je pak, suprotno tomu, usmjeren na poboljšanje postojećih ili uvođenje novih praksi. Cilj je ovoga članka dati doprinos spoznajama o financiranju državnih arhiva kroz obradu jedne podteme, a to je njihovo financiranje javnim (proračunskim) sredstvima namijenjenim financiranju programa javnih potreba u kulturi Republike Hrvatske. Analizom je obuhvaćeno posljednje desetogodišnje razdoblje. Konkretno, analizirani su podatci o sredstvima odobrenim u 2009. za 2010. godinu i dalje, zaključno sa sredstvima odobrenim za 2018. godinu, nakon čega dolazi do promjene modela financiranja programskih aktivnosti državnih arhiva. Razlozi su odabira toga razdoblja i metodološke naravi, u smislu mogućnosti provedbe cjelovite analize podataka. U kontekstu teme, bitne pretpostavke za to su konzistentnost mreže državnih arhiva i modela financiranja programa javnih potreba u kulturi, te dostupnost cjelovitih podataka. ${ }^{1}$ Podatci o broju i vrstama odobrenih programa između ostaloga pokazuju na koje su aktivnosti, u kojem opsegu i u kojem kontinuitetu (kratkoročno i dugoročno) arhivi stavljali naglasak, te u kojoj su mjeri one bile podudarne $s$ njihovim osnovnim zadaćama. Zajedno s pregledom kretanja iznosa odobrenih sredstava, takvi su podatci zasigurno i jedan od pokazatelja odnosa države prema javnoj arhivskoj službi i sustavu arhiva Republike Hrvatske. Rezultati mogu poslužiti i za usporedbu s obilježjima financiranja drugih djelatnosti u kulturi iz programa javnih potreba u kulturi, posebno srodnih baštinskih ustanova (knjižnice, muzeji). Mogućnost praktične primjene rezultata u tome je što daju podlogu za preispitivanje postojećega i poboljšanje budućega pristupa državnih arhiva u planiranju arhivskih programa, kao i metodologije financiranja od strane mjerodavnoga Ministarstva kulture.

Potrebu za takvim istraživanjima potvrđuje i recentna praksa Ministarstva kulture, koje je, po provedenom Pozivu za predlaganje programa javnih potreba

\footnotetext{
1 Na mrežnim stranicama Ministarstva kulture postoje podatci o odobrenim programima javnih potreba u kulturi i u ranijem razdoblju, od 2006. nadalje. Međutim, nema podataka o programima arhivske djelatnosti u 2008. i 2009. godini, što bi bilo posebno relevantno za ovaj članak. Nedostatak tih podataka ograničava mogućnost cjelovite usporedbe odobrenih programa unutar arhivske djelatnosti ili pak programa arhivske i drugih programskih djelatnosti u dužem vremenskom razdoblju. Nadalje, tijekom 2007. i 2008. osnivano je nekoliko novih državnih arhiva, što također uvjetuje mogućnost njihove međusobne usporedbe u dužem razdoblju. Usp. "Financiranje," Ministarstvo kulture Republike Hrvatske, pristupljeno 21. ožujka 2019., https://www.min-kulture.hr/default.aspx?id=2570.
} 
u kulturi za 2019., započelo s objavom usporednih analiza prijavljenih programa i odobrenih sredstava u toj godini, »s ciljem valorizacije dosadašnjeg učinka i dobivanja smjernica za učinkovitiju raspodjelu proračunskih sredstava «. ${ }^{2}$ Objavljen je i pregled izravno raspodijeljenih sredstava za programske aktivnosti ustanova u mjerodavnosti Ministarstva po vrstama ustanova (arhivi, muzeji, ostali) te programskim djelatnostima. ${ }^{3}$ Početkom ožujka 2019., Ministarstvo je kulture najavilo i početak rada na izvještaju o hrvatskoj kulturnoj politici, prvoga takvog sveobuhvatnog dokumenta koji se izrađuje dvadeset godina nakon što je objavljen Nacionalni izvještaj o kulturnoj politici Republike Hrvatske iz 1998. godine, istaknuvši da je takva analiza neophodna za pozicioniranje kulture i kulturnih strateških projekata u temeljni nacionalni strateški dokument, Nacionalnu razvojnu strategiju Hrvatske do 2030. godine. ${ }^{4} \mathrm{U}$ kontekstu arhivske djelatnosti, vrlo je važan Nacionalni plan razvoja arhivske djelatnosti, čije je donošenje od strane Vlade Republike Hrvatske na prijedlog Ministarstva kulture predviđeno arhivskim zakonom iz 2018. godine. Svrha je toga dokumenta urediti aktivnosti i mjere kojima će se osigurati uvjeti za daljnji razvoj arhivske djelatnosti. ${ }^{5}$ Jedan od tih uvjeta zasigurno je i financiranje.

\section{O financiranju državnih arhiva u dosadašnjim istraživanjima}

U dosadašnjim radovima u kojima se donekle obrađuje tema financiranja državnih arhiva uglavnom nedostaju konkretni brojčani pokazatelji. U nekoliko koautorskih radova te se teme dotiču Stjepan Ćosić i Vlatka Lemić. Problematiku financiranja državnih arhiva stavljaju u širi kontekst financiranja kulture kao djelatnosti, prisutnoga trenda smanjenja javnoga financiranja, te potrebe arhiva da se kao javne ustanove koje financira država prilagode ekonomskim načelima poslovanja, što podrazumijeva i pronalaženje alternativnih načina financiranja (vlastiti prihodi, sponzorstva, donacije, domaći i međunarodni programi i projekti). U dijelu koji se odnosi na stjecanje vlastitih prihoda, naglašavaju trajno aktualnu važnost pravnih i etičkih pitanja razgraničenja temeljnih i dodatnih, naplativih usluga državnih arhiva. ${ }^{6}$ Važnost upravljanja arhivskim programima,

\footnotetext{
2 "Analiza financiranja programa javnih potreba u kulturi," Ministarstvo kulture Republike Hrvatske, pristupljeno 13. ožujka 2019., https://www.min-kulture.hr/default.aspx?id=19563.

3 “Odobreni programi ustanova u nadležnosti Ministarstva kulture u 2019. godini," Ministarstvo kulture Republike Hrvatske, pristupljeno 13. ožujka 2019., https://www.min-kulture.hr/default.aspx?id $=21799$.

4 “Započeo rad na analitičkom izvještaju o hrvatskoj kulturnoj politici," Ministarstvo kulture Republike Hrvatske, pristupljeno 13. ožujka 2019., https://www.min-kulture.hr/novost/default.aspx?id=21895. Usp. Zakon o sustavu strateškog planiranja i upravljanja razvojem Republike Hrvatske, NN 123/2017.

5 Usp. Zakon o arhivskom gradivu i arhivima, NN 61/2018, čl. 48 i 54.

6 Usp. Stjepan Ćosić i Vlatka Lemić, "Rad arhiva u uvjetima suprotstavljenih utjecaja: država-društvokorisnici," u Izlaganja s 2. kongresa hrvatskih arhivista (elektronička grada): arhivi i društvo - izazovi suvremenog doba / Drugi kongres hrvatskih arhivista, Dubrovnik, listopad 2005., ur. Ivana Prgin (Zagreb:
} 
uključujući i financijske resurse, naglašava i Jozo Ivanović u Priručniku iz arhivistike iz 2010. godine. Istaknuvši nedostatak domaće literature o tome, u posebnom je poglavlju vrlo pregledno obradio teme definiranja arhivskih programa, planiranja i praćenja, organizacije, upravljanja ljudskim resursima, prostora i opreme, financijskih resursa te informacijskih sustava i dokumentacije. ${ }^{7}$ Polazeći od toga da su programi državnih arhiva u pravilu neprofitni i da se oslanjanju na sredstva koja pristižu iz stalnoga izvora financiranja, a u kontekstu rastuće konkurencije zahtjeva drugih organizacija koje računaju na iste izvore sredstava i politike smanjenja javnih troškova, upućuje na potrebu aktivnijega pristupa i utvrđivanje dugoročne politike osiguranja i razvoja resursa. U skupini mogućih izvora financiranja, uz proračunska sredstva (troškovi redovne djelatnosti, programi poticanja djelatnosti, ostali javni izvori) te već spomenute vlastite prihode, donacije i sponzorstva, veliki potencijal za povećanje resursa prepoznaje u volontiranju i stručnoj praksi, te sposobnosti korištenja drugih vanjskih resursa koji mogu rasteretiti postojeće resurse arhivâ i ostvariti im financijske uštede (primjerice smještaj arhivskoga gradiva koje čeka na preuzimanje u adekvatnim prostorima, u režimu sličnom izdvojenom spremištu arhiva, ali na trošak posjednika gradiva). ${ }^{8} \mathrm{U}$ radu o menadžmentu arhivskih ustanova i programa, Kristijan Karajić ocjenjuje kako je »u Hrvatskoj još na snazi zastarjeli sustav financiranja kulture i njezinih djelatnosti, koji iz godine u godinu zahtijeva sve veći udio proračunskih sredstava, a dobiva sve manje«. Pozivajući se na zaključke drugih autora, Karajić također naglašava kako kulturni proizvodi najčešće nisu prioritetno vrednovani na tržištu, te se često ne priznaje postojanje tržišta kulturnih proizvoda. Pretežito financiranje kulturnih djelatnosti iz proračuna, utječe na širu percepciju o kulturi, a time i o arhivskoj djelatnosti, kao privilegiranoj djelatnosti, odnosno zajedničkoj potrošnji o kojoj skrbi država. ${ }^{9}$ Vrijedan doprinos obradi teme završni je rad Irme Sugar-Glavaš o financiranju kulture i umjetnosti u Hrvatskoj, napisan 2018. u okviru studija financijskoga menadžmenta na Fakultetu ekonomije i turizma „Dr. Mijo Mirković” Sveučilišta Jurja Dobrile u Puli. Za razliku od prethodno opisanih, u tom radu mogu se pronaći konkretni brojčani pokazatelji o financiranju programa kulturnih djelatnosti, među njima i arhivske, od 2008. do

Hrvatsko arhivističko društvo, 2005), str. 7-8; Stjepan Ćosić i Vlatka Lemić, "Rad arhiva u uvjetima suprotstavljenih utjecaja: država - društvo - korisnici," Arhivski vjesnik 49 (2006): str. 14-15; Stjepan Ćosić i Vlatka Lemić, "Problemi arhivske službe u Hrvatskoj," u Arhivska služba na pragu pristupa Hrvatske Europskoj uniji: 41. savjetovanje, 11. - 13. listopada 2006., Karlovac, Hrvatska, ur. Deana Kovačec (Zagreb: Hrvatsko arhivističko društvo, 2007), str. 10-11; Stjepan Ćosić i Vlatka Lemić, "Problemi arhivske službe u Hrvatskoj," Arhivski vjesnik 51 (2008): str. 20-21.

Jozo Ivanović, Priručnik iz arhivistike: I. dio (Zagreb: Hrvatski državni arhiv, 2010), str. 139-226.

8 Usp. Ivanović, Priručnik iz arhivistike, str. 200-218.

9 Kristijan Karajić, "Menadžment arhivskih ustanova i programa," Hrvatska i komparativna javna uprava: ćasopis za teoriju i praksu javne uprave 16, br. 2 (2016): str. 325-326. Usp. Jadran Antolović, Menadžment u kulturi (Zagreb: Hadrian, 2009), str. 107. 
2017. godine. ${ }^{10} \mathrm{Na}$ posljednjem, Petom kongresu hrvatskih arhivista (Zadar, 24.27. listopada 2017.), kroz tridesetak plenarnih i panel predavanja na temu Arhivi u Hrvatskoj: (retro)perspektiva, obrađeni su različiti aspekti organizacije i upravljanja arhivima i javnom arhivskom službom (zakonodavstvo, strateško planiranje, pozicioniranje arhiva u globalnom okruženju, obrazovanje stručnjaka) te postignuća u različitim područjima suvremene arhivske prakse (obrada i opis gradiva, vrednovanje, zaštita gradiva, dostupnost gradiva, razvoj usluga namijenjenih široj javnosti, podrška stvarateljima). Iako je manjim dijelom bila zahvaćena u izlaganjima Ivane Prgin Strateško planiranje i arhivska služba - pozicije i utjecaji i Dražena Kušena Arhivi između redovne djelatnosti, posebnih programa $i$ komercijalne "dodane vrijednosti", tema "(retro)perspektive" financiranja arhiva i javne arhivske službe ostala je neobrađena. ${ }^{11}$

\section{3. $\mathrm{O}$ financiranju državnih arhiva $u$ arhivskom zakonodavstvu}

Zakonom o arhivskom gradivu i arhivima iz 1997. godine bilo je određeno da se sredstva za rad državnih arhiva osiguravaju u državnom proračunu, a da sredstva za rad ostalih arhiva (arhivi jedinica lokalne samouprave i uprave, zajednički arhivi više jedinica lokalne samouprave i uprave, specijalizirani i privatni arhivi) osiguravaju njihovi osnivači. Arhivima je ostavljena mogućnost ostvarivanja dodatnih sredstava (dobiti) obavljanjem njihove djelatnosti, ali uz isključivu namjenu za obavljanje i razvoj djelatnosti arhiva. ${ }^{12}$ Hrvatski sabor donio je 4. svibnja 2017. godine Zakon o izmjenama i dopunama Zakona o arhivskom gradivu i arhivima. Te su se izmjene i dopune najvećim dijelom odnosile na uvjete korištenja gradiva u arhivima, njegovo evidentiranje izvan arhiva (kod stvaratelja i/ili posjednika) i uvjete predaje arhivima. Financiranje arhiva sredstvima državnoga proračuna tim zakonskim izmjenama nije bilo zahvaćeno. Međutim, pojedine odredbe o korištenju gradiva u arhivima odnosile su se na kriterije plaćanja naknada arhivima za umnožavanje i objavu reprodukcija gradiva, što je u određenoj mjeri imalo utjecaj na ostvarivanje prihoda arhiva iz obavljanja djelatnosti. ${ }^{13}$ U novom arhivskom zakonu iz 2018. zadržan je opisani model financiranja, prema kojem se sredstva za rad državnih arhiva osiguravaju u

\footnotetext{
10 Irma Šugar-Glavaš, "Financiranje kulture i umjetnosti u Republici Hrvatskoj," (završni rad, Sveučilište Jurja Dobrile u Puli, 2018), pristupljeno 25. ožujka 2019., https://repozitorij.unipu.hr/islandora/ object/unipu:2443/preview.

11 Usp. Ivana Prgin, "Strateško planiranje i arhivska služba - pozicija i utjecaji," u Arhivi u Hrvatskoj - (retro)perspektiva: 5. kongres hrvatskih arhivista, 24. - 27. listopada 2017., Zadar, ur. Silvija Babić (Zagreb: Hrvatsko arhivističko društvo, 2017), str. 23-35. Integralni tekst izlaganja Dražena Kušena nije objavljen u zborniku radova s kongresa. Kraći osvrt na to izlaganje: Boris Suljagić, "5. kongres hrvatskih arhivista Arhivi u Hrvatskoj - (retro)perspektiva, Hrvatsko arhivističko društvo - Državni arhiv u Zadru. Zadar, 24. - 27. listopada 2017.," Arhivski vjesnik 61(2018): str. 286.

12 Zakon o arhivskom gradivu i arhivima, NN 105/1997, čl. 49 i 51.

13 Usp. Zakon o izmjenama i dopunama Zakona o arhivskom gradivu i arhivima, NN 46/2017.
} 
državnom proračunu, a sredstva za rad ostalih arhiva osiguravaju njihovi osnivači. Uz prethodno navedene, u skupini ostalih arhiva, novim je zakonom predviđena mogućnost osnivanja arhiva u sastavu kao podružnica, odnosno ustrojstvenih jedinica pravnih osoba. Nešto drugačije formulirana je zakonska odredba o stjecanju prihoda iz drugih izvora. Propisano je da se "sredstva za rad arhiva osiguravaju i prihodima od obavljanja djelatnosti arhiva i na drugi način u skladu sa zakonom«, pri čemu je izostavljena odredba iz prijašnjega zakona o korištenju vlastitih prihoda isključivo za obavljanje i razvoj djelatnosti arhiva. ${ }^{14}$ Detaljnija pravila o načinu korištenja vlastitih prihoda ustanova u kulturi koje su proračunski korisnici državnoga proračuna, u koje spadaju i državni arhivi, utvrđene su posebnim pravilnikom Ministarstva kulture od 17. svibnja 2018. godine. Odredbe tog Pravilnika "odnose se na prihode što ih ustanove ostvare na tržištu od obavljanja osnovne i ostalih djelatnosti za koje su registrirane, kao i od drugih pomoćnih djelatnosti: iznajmljivanje prostora i opreme, obavljanje ugostiteljskih usluga, poslova fotokopiranja, prodaje suvenira, promotivnih materijala, organizacije stručnih skupova, radionica i slično, a koje poslove mogu obavljati i drugi pravni subjekti izvan proračuna i čijim obavljanjem ustanove ostvaruju prihode u skladu sa zakonom o proračunu «. ${ }^{15}$

\section{Uloga Ministarstva kulture RH u financiranju državnih arhiva}

Arhivska djelatnost u Hrvatskoj u mjerodavnosti je Ministarstva kulture, te se sredstva za rad državnih arhiva osiguravaju iz udjela toga Ministarstva u ukupnom planiranom državnom proračunu. U tu skupinu spadaju Hrvatski državni arhiv kao središnja i matična arhivska ustanova te 17 područnih državnih arhiva (Bjelovar, Dubrovnik, Gospić, Karlovac, Međimurje - Štrigova, Osijek, Pazin, Rijeka, Sisak, Slavonski Brod, Split, Šibenik, Varaždin, Virovitica, Vukovar, Zagreb, Zadar). ${ }^{16}$ Sredstvima državnoga proračuna financira se i Hrvatski memorijalno-dokumentacijski centar Domovinskog rata, čiji je osnivač kao javne znanstvene ustanove - specijaliziranoga arhiva Republika Hrvatska, a prava i

\footnotetext{
14 Zakon o arhivskom gradivu i arhivima, NN 61/2018, čl. 36.

15 Usp. Pravilnik o načinu korištenja vlastitih prihoda ostvarenih od obavljanja osnovne i ostale djelatnosti ustanova u kulturi, NN 47/2018, čl. 2.

16 Uredbom Vlade Republike Hrvatske od 30. lipnja 2008. formalno je osnovan i Državni arhiv u Križevcima, kao područni državni arhiv za obavljanje arhivske službe na području Koprivničko-križevačke županije. Međutim, taj arhiv do danas nije započeo $s$ radom, jer za to nisu ostvareni tehnički uvjeti, ponajprije u pogledu prostora i opreme potrebne za rad. Iz bilješki sa sastanaka Hrvatskoga arhivskoga vijeća iz 2018. vidljivo je da je Grad Križevci odredio konkretan prostor i predložilo njegovu adaptaciju za potrebe državnoga arhiva. Usp. Uredba o osnivanju Državnog arhiva u Križevcima, NN 77/2008; "Sažetak 22. sjednice Hrvatskog arhivskog vijeća održane 12. lipnja 2018. u Ministarstvu kulture, Zagreb, Runjaninova 2" i "Sažetak Konstituirajuće sjednice Hrvatskog arhivskog vijeća održane 10. prosinca 2018. u Ministarstvu kulture, Zagreb, Runjaninova 2," Ministarstvo kulture Republike Hrvatske, pristupljeno 12. ožujka 2019., https://www.min-kulture.hr/default.aspx?id=365.
} 
dužnosti osnivača obavlja Ministarstvo kulture u okviru ovlasti Vlade Republike Hrvatske. ${ }^{17} \mathrm{Uz}$ navedene državne arhive, to je jedini dosad osnovani arhiv sa statusom posebne ustanove. ${ }^{18}$ Stoga je i taj specijalizirani arhiv uvršten $u$ analizu provedenu za potrebe ovoga članka. Po osnovi obavljanja osnivačkih prava, Ministarstvo kulture osigurava nabrojanim arhivima propisana sredstva za rad. To se ponajprije odnosi na sredstva za redovnu djelatnost koja uključuju sredstva za rashode za zaposlene i prijevoz, te sredstva za materijalne i financijske rashode. Osim sredstava za redovnu djelatnost, državnim se arhivima na godišnjoj razini dodjeljuju određena sredstva za programsku djelatnost (posebne programe). Do 2018. godine državni su arhivi posebne programe prijavljivali na godišnje javne pozive za predlaganje programa javnih potreba u kulturi, kao i svi ostali prijavitelji (samostalni umjetnici; umjetničke organizacije; ustanove u kulturi; udruge; pravne i fizičke osobe koje obavljaju djelatnost u kulturi; pravne i fizičke osobe za potrebe zaštite i očuvanja kulturnih dobara i arheološke baštine). Prema novom modelu financiranja koji je uveden 2018., umjesto prijave svakoga pojedinog programa na godišnji javni poziv poput ostalih prijavitelja, programi 48 ustanova kojima je osnivač Ministarstvo kulture - među kojima su i svi nabrojani arhivi - planiraju se i ugovaraju zajedno s ostalim troškovima (materijalni izdatci i plaće). Time je, kako se obrazlaže u dokumentima Ministarstva kulture, "osiguran bolji uvid $\mathrm{u}$ izdatke i upravljanje financijskim sredstvima ustanova, kao i smanjenje administrativnih poslova ${ }^{19}$

Pravni okvir za financiranje programskih aktivnosti na temelju prethodno provedenih javnih poziva čini Zakon o financiranju javnih potreba u kulturi. U proteklom razdoblju nekoliko je puta mijenjan, a na snazi je tekst s izmjenama iz 2009. godine. ${ }^{20}$ Zakonske odredbe detaljnije su razrađene posebnim Pravilnikom o izboru i utvrđivanju programa javnih potreba u kulturi, čije je donošenje u mjerodavnosti ministra kulture. Prvi takav pravilnik donesen je 2001., a potom

17 Zakon o Hrvatskom memorijalno-dokumentacijskom centru Domovinskog rata, NN 178/2004, čl. 2 i 17; Usp. "Statut Hrvatskog memorijalno-dokumentacijskog centra Domovinskog rata, Zagreb, 2005.," Hrvatski memorijalno-dokumentacijski centar Domovinskoga rata, pristupljeno 14. ožujka 2019., https://centardomovinskograta.hr/wp-content/uploads/2013/05/Statut.pdf.

18 Usp. Nenad Bukvić, "Arhivska služba i arhivsko zakonodavstvo u funkciji zaštite gradiva muzejskih ustanova," Arhivski vjesnik 57 (2014): str. 72.

19 "Odobreni programi ustanova u nadležnosti Ministarstva kulture u 2019. godini”; "Godišnje izvješće Ministarstva kulture 2018.," Ministarstvo kulture Republike Hrvatske, pristupljeno 26. ožujka 2019., https://www.min-kulture.hr/userdocsimages/2018\%20poziv/obrasci/godi\%C5\%A1 njak_2019 -02-20_023.pdf.

${ }^{20}$ Hrvatski sabor usvojio je 9. studenoga 1990. godine Zakon o fondovima za kulturu. Izmjenama i dopunama od 24. ožujka 1993. naziv je Zakona promijenjen u Zakon o financiranju javnih potreba u kulturi. Posljednje izmjene toga Zakona od 20. ožujka 2009. odnosile su se na mjerodavnost tijela na području Grada Zagreba. Usp. Zakon o fondovima za kulturu, NN 47/1990; Zakon o izmjenama i dopunama Zakona o fondovima za kulturu, NN 27/1993; Zakon o izmjeni Zakona o financiranju javnih potreba u kulturi, NN38/2009. Usp. Ivana Bestvina Bukvić, Marija Mihaljević i Ivana Tokić, "Kulturna politika i utjecaj zakonskog okvira na financiranje kazališta," Pravni vjesnik: časopis za pravne i društvene znanosti pravnog fakulteta Sveučilista J. J. Strossmayera u Osijeku 31, br. 3-4 (2015): str. 156-159. 
je više puta mijenjan. Na snazi je tekst pravilnika iz 2016. godine. ${ }^{21}$ Prethodno navedeni Zakon i Pravilnik posebno su važni jer se njima, između ostaloga, utvrđuju kriteriji za dodjeljivanje financijskih sredstava za provođenje programa javnih potreba u kulturi. Pod takvim programima Zakon podrazumijeva sve oblike "poticanja i promicanja kulture i kulturnih djelatnosti što pridonose razvitku i unapređivanju svekolikog kulturnog života u Republici Hrvatskoj«, s time da se pri njihovu utvrđivanju "polazi od potreba i postignutog stupnja razvitka kulture i kulturnih djelatnosti«. Republika Hrvatska, županije, Grad Zagreb, općine i gradovi donose programe javnih potreba u kulturi te za njihovo provođenje osiguravaju sredstva iz svojih proračuna. Javne potrebe u kulturi za koje se sredstva osiguravaju iz državnoga proračuna $\mathrm{RH}$ su »kulturne djelatnosti i poslovi, akcije i manifestacije u kulturi od interesa za Republiku Hrvatsku« detaljno navedene u članku 9 toga Zakona. Među njima, razvrstanima u dvadesetak kategorija, navedeno je i obavljanje arhivske djelatnosti. ${ }^{22}$ Kao posebna kategorija programa javnih potreba u kulturi, u Pravilniku je navedeno unapređivanje arhivske djelatnosti. Programske aktivnosti arhiva podudarne su is nekoliko drugih zasebnih programskih djelatnosti (kategorija) utvrđenih Pravilnikom, poput međunarodne kulturne suradnje, informatizacije, digitalizacije te investicijske potpore (rekonstrukcije, sanacije, adaptacije, investicijsko održavanje i opremanje objekata). ${ }^{23}$

Konkretne programske djelatnosti koje su u pojedinoj godini uvrštene u program javnih potreba u kulturi Republike Hrvatske, kao i promjene u tom dijelu, vidljive su iz godišnjih poziva za predlaganje programa za financiranje. Kod nekoliko programskih djelatnosti u pojedinim je godinama došlo do podjele na više pojedinačnih (primjerice programi zaštite i očuvanja kulturnih dobara podijeljeni su od 2014. godine na programe zaštite i očuvanja nepokretnih kulturnih dobara i programe zaštite i očuvanja pokretnih kulturnih dobara; na više programskih djelatnosti od te su godine podijeljene i književne manifestacije, te

21 Usp. Pravilnik o izboru i utvrđivanju programa javnih potreba u kulturi, NN 7/2001; Pravilnik o izmjenama i dopunama Pravilnika o izboru i utvrđivanju programa javnih potreba u kulturi, NN 60/2001; Pravilnik o izmjenama i dopunama Pravilnika o izboru i utvrđivanju programa javnih potreba u kulturi, NN 135/2006; Pravilnik o izboru i utvrđivanju programa javnih potreba u kulturi, NN 137/2008; Pravilnik o izmjeni Pravilnika o izboru i utvrđivanju programa javnih potreba u kulturi, NN 57/2009; Pravilnik o izmjeni Pravilnika o izboru i utvrđivanju programa javnih potreba u kulturi, NN 62/2009; Pravilnik o izboru i utvrđivanju programa javnih potreba u kulturi, NN 69/2012; Pravilnik o izmjeni i dopunama Pravilnika o izboru i utvrdivanju javnih potreba u kulturi, NN 44/2013; Pravilnik o izmjeni Pravilnika o izboru i utvrđivanju javnih potreba u kulturi, NN 91/2013; Pravilnik o izmjeni Pravilnika o izboru i utvrđivanju javnih potreba u kulturi, NN 72/2015; Pravilnik o izboru i utvrđivanju programa javnih potreba u kulturi, NN 55/2016.

22 Zakon o fondovima za kulturu, NN 47/1990, čl. 9; Zakon o izmjenama i dopunama Zakona o fondovima za kulturu, NN 27/1993, čl. 2.

23 Pravilnik o izboru i utvrđivanju programa javnih potreba u kulturi, NN 7/2001, čl. 4; Pravilnik o izboru i utvrđivanju programa javnih potreba u kulturi, NN 137/2008, čl. 6; Pravilnik o izboru i utvrđivanju programa javnih potreba u kulturi, NN 69/2012, čl. 6; Pravilnik o izboru i utvrđivanju programa javnih potreba u kulturi, NN 55/2016, čl. 6. 
potpore za izdavanje knjiga, časopisa i elektroničkih publikacija). Za dio programa mijenjana je programska djelatnost u okviru koje su financirani (primjerice u razdoblju 2010.-2012. programi plesne umjetnosti činili su jednu programsku djelatnost zajedno s glazbom i glazbeno-scenskim umjetnostima, a od 2013. činili su programsku djelatnost zajedno s dramskim i izvedbenim umjetnostima). Dio programskih djelatnosti uveden je od 2012. nadalje (primjerice programi poduzetništva u kulturi, inovativne umjetničke i kulturne prakse), a dio je njih u program javnih potreba u kulturi RH uvršten samo u pojedinim godinama (primjerice neprofitni mediji i novinarski radovi; razvojna istraživanja, evaluacija i edukacija na području kulture i medija; izrada dokumentacije za projekte EU fondova). ${ }^{24}$ Važno je istaknuti da arhivsku djelatnost nalazimo uvrštenu kao zasebnu programsku djelatnost u svim godišnjim pozivima u analiziranom razdoblju.

Kao temeljni kriteriji vrednovanja prijedloga prijavljenih u svim programskim djelatnostima, Pravilnikom o izboru i utvrđivanju programa javnih potreba u kulturi postavljeni su: kvaliteta i sadržajna inovativnost ponuđenoga programa; važnost programa za očuvanje kulturne baštine i kulturnoga identiteta; primjena novih tehnologija, partnerstvo, koprodukcije i umrežavanje; ekonomičnost i dugoročnost programa; promicanje hrvatske kulture u svijetu i uključenost u europske i međunarodne kulturne mreže i projekte; opći interes za kulturni razvitak kao i posebni interesi prema područjima obrazovanja, znanosti, gospodarstva, turizma i dr.; promicanje programa za djecu i mlade; sudjelovanje osoba s invaliditetom u programu te prilagođenost programa osobama s invaliditetom; podrška jedinica lokalne i područne (regionalne) samouprave u ostvarivanju programa; podrška međunarodnih vladinih i nevladinih organizacija u ostvarivanju programa; financijska potpora iz drugih izvora. ${ }^{25} \mathrm{Na}$ osnovu tih temeljnih kriterija, Hrvatsko je arhivsko vijeće 4. svibnja 2017. usvojilo dodatne Smjernice za vrednovanje programa arhivske djelatnosti, koje je izradila služba Ministarstva kulture mjerodavna za arhivsku djelatnost. ${ }^{26}$ Njima je utvrđeno da će se posebno podržavati programi arhiva "koji su usmjereni na razvoj osnovne djelatnosti arhiva, na obogaćivanje fondova i zbirki javnih arhiva gradivom koje se ne preuzima po službenoj dužnosti, na dugoročno očuvanje arhivskoga gradiva i na razvoj usluga i programa koji su namijenjeni korisnicima gradiva i javnosti«. Smjernicama je uvedeno podnošenje prijedloga za financiranje u pet potprogramskih djelatnosti: 1. zaštita arhivskoga gradiva; 2. prikupljanje (otkup) arhiv-

\footnotetext{
24 “Javni pozivi," Ministarstvo kulture Republike Hrvatske, pristupljeno 4. travnja 2019., https://www. min-kulture.hr/default.aspx?id=68.

25 Pravilnik o izboru i utvrđivanju programa javnih potreba u kulturi, NN 69/2012, čl. 7; Pravilnik o izboru i utvrđivanju programa javnih potreba u kulturi, NN 55/2016, čl. 7.

26 "Sažetak 17. sjednice Hrvatskog arhivskog vijeća održane 4. svibnja 2017. u Ministarstvu kulture, Zagreb, Runjaninova 2," Ministarstvo kulture Republike Hrvatske, pristupljeno 14. ožujka 2019., https:// www.min-kulture.hr/default.aspx?id=365.
} 
skoga gradiva; 3. izdavačka djelatnost; 4. izložbena i promotivna djelatnost; 5 . znanstvena djelatnost, stručno usavršavanje i razvoj. ${ }^{27}$ Slična tipologija postojala je i u prethodnom razdoblju, ali uz razdvajanje srodnih aktivnosti na više samostalnih potprogramskih djelatnosti. Primjerice, aktivnosti grupirane u podprogramsku djelatnost zaštite arhivskoga gradiva prethodno su mogle biti prijavljene kao više samostalnih djelatnosti (zaštita arhivskoga gradiva - mikrofilmiranje, zaštita arhivskoga gradiva - restauriranje i konzerviranje, zaštitno snimanje arhivskoga gradiva, zaštita fonogradiva i glazbene baštine RH). Prema tim smjernicama vrednovani su programi arhivske djelatnosti prijavljeni u 2017. za 2018. godinu, nakon čega je, kako je već opisano, došlo do promjene metodologije, odnosno izravnoga financiranja programske djelatnosti državnih arhiva.

\section{Analiza financiranja državnih arhiva kroz programe javnih potreba u kulturi Republike Hrvatske}

Podatci o programima financiranim sredstvima državnoga proračuna namijenjenim za programe javnih potreba u kulturi Republike Hrvatske dostupni su na mrežnim stranicama Ministarstva kulture. Strukturirani su po godinama, unutar svake godine po programskim djelatnostima, a unutar svake programske djelatnosti po prijaviteljima i odobrenim pojedinačnim programima. Kako bi se došlo do zaključaka o osnovnim obilježjima (smjeru kretanja) financiranja državnih arhiva, za potrebe ovoga članka svi su podatci koji se odnose na njihove pojedinačne programe izdvojeni i potom sabrani po više kriterija (po programskim djelatnostima, po vrstama programa unutar pojedine programske djelatnosti, po državnim arhivima). Prilikom analize krenulo se od pretpostavke da su podatci o odobrenim programima državnih arhiva na mrežnim stranicama Ministarstva kulture potpuni. Međutim, na temelju usporedbe tih podataka $s$ izvještajima pojedinih državnih arhiva o njihovim programskim aktivnostima, uočeno je da dio podataka mjestimice ipak nedostaje. Primjerice, utvrđeno je da nema podataka o odobrenim sredstvima za tri trogodišnja programa Hrvatskoga državnog arhiva iz razdoblja 2014.-2016. (Digitalizacija Vjesnikove novinske i fotodokumentacije, Digitalizacija gradiva o Prvom svjetskom ratu, Obilježavanje stogodišnjice Prvoga svjetskoga rata). ${ }^{28}$ Podatci o tome preuzeti su iz drugih izvora, tj. dokumentacije o provedbi tih programa (ugovori, izvještaji) i uvršteni u zbirnu analizu u ovom članku. ${ }^{29}$ Nadalje, iako je iz javnih poziva vidljivo da je od 2010.

\footnotetext{
27 "Smjernice za vrednovanje arhivskih programa," Ministarstvo kulture Republike Hrvatske, pristupljeno 14. ožujka 2019., https://www.min-kulture.hr/default.aspx?id=18810.

28 Usp. "Izvještaj o radu Hrvatskoga državnog arhiva u 2016. godini, Zagreb, veljača 2017.," Hrvatski državni arhiv, pristupljeno 25. ožujka 2019., http://www.arhiv.hr/Portals/0/Dokumenti/Planovi\%20i\% 20izvje\%C5\%A1\%C4\%87a/Izvje\%C5\%A1\%C4\%87e\%20o\%20radu\%20HDA\%20u\%202016.\% 20godini.pdf?ver=2017-03-23-092024-000.

29 Hrvatski državni arhiv, Pismohrana, Klasa: 402-03/17-02/01.
} 
do 2017. u programe javnih potreba u kulturi Republike Hrvatske bila uvrštena informatizacija ustanova u kulturi (nabava informatičke opreme), pojedinačni podatci o tome na mrežnim su stranicama Ministarstva kulture dostupni od 2013. nadalje. U 2018. godini sredstva za tu namjenu prijaviteljima nisu dodijeljena zasebno, nego kroz programe investicijske potpore te su i iskazana u toj programskoj djelatnosti. $\mathrm{Na}$ temelju opisa (naziva) pojedinačnih programa nije moguće zaključiti je li takav pristup u pogledu financiranja programa informatizacije možda bio primijenjen i u razdoblju 2010.-2013. Unatoč opisanim poteškoćama, u analizi se polazi od pretpostavke da su podatci raspoloživi u dovoljnoj mjeri da realno oslikavaju osnovna obilježja financiranja državnih arhiva, tj. da podatci koji eventualno nedostaju u bitnom ne mijenjaju ukupnu sliku.

Rezultati analize pokazuju da su u naznačenom razdoblju državnim arhivima odobravani programi u šest programskih djelatnosti: arhivska djelatnost $(\mathrm{AD})$, međunarodna kulturna suradnja (MKS), digitalizacija arhivske, knjižnične i muzejske građe (DIG), informatizacija (INF), investicijska potpora (INV) i programi zaštite na nepokretnim kulturnim dobrima (ZNKD). Ukupno je odobreno 1.209 programa (jednogodišnjih i trogodišnjih) ukupne vrijednosti nešto veće od 87,8 milijuna kuna. U odnosu na programe odobrene svim prijaviteljima u tih šest programskih djelatnosti, udio programa državnih arhiva čini nešto manje od 8\% ukupnoga broja odobrenih programa, odnosno 6\% ukupno odobrenoga iznosa sredstava. Pritom je najveći udjel državnih arhiva ostvaren unutar arhivske djelatnosti, a zatim slijede veći udjeli unutar programa digitalizacije, informatizacije i investicijske potpore (Tablica 1).

Ako se međusobno usporede samo ukupno odobreni iznosi sredstava za programe državnih arhiva, najveći su udjeli sredstava za investicijsku potporu $(54,66 \%)$ i arhivsku djelatnost $(40,44 \%)$, a zatim slijede udjeli sredstva za informatizaciju $(1,67 \%)$, digitalizaciju $(1,58 \%)$, zaštitu nepokretnih kulturnih dobara $(1,4 \%)$ i međunarodnu kulturnu suradnju $(0,25 \%)$. Iz toga je vidljivo da sredstva odobrena u prve dvije programske djelatnosti čine 95,1\% ukupno odobrenih sredstva za programe državnih arhiva.

Širi kontekst tim podatcima daje analiza Irme Šugar-Glavaš, prema kojoj su prosječna godišnja ulaganja iz proračuna Ministarstva kulture u sve kulturne djelatnosti, projekte, programe i potpore od 2010. do 2017. godine iznosila $289.443 .125 \mathrm{kn}^{30}$ Gledajući to isto razdoblje, prosječna godišnja ulaganja u programe državnih arhiva iznosila su $9.935 .334 \mathrm{kn}$, odnosno 3,43\% ukupnih prosječnih godišnjih ulaganja u programe svih kulturnih djelatnosti. Kretanje stvarnih godišnjih ulaganja u programe državnih arhiva unutar šest spomenutih programskih djelatnosti ilustriraju dva grafikona u nastavku. Zbog velike razlike u ukupnim iznosima po programskim djelatnostima, a s ciljem prezentacije što

30 Šugar-Glavaš, "Financiranje kulture," str. 15. 
Tablica 1. Financiranje programa državnih arhiva prema programskim djelatnostima uvrštenim u programe javnih potreba u kulturi Republike Hrvatske od 2010. do 2018. godine

\begin{tabular}{|l|c|c|c|c|c|c|}
\hline \multirow{2}{*}{$\begin{array}{l}\text { Programska } \\
\text { djelatnost }\end{array}$} & $\begin{array}{c}|c| \\
\text { Broj } \\
\text { odobre- } \\
\text { nih } \\
\text { programa }\end{array}$ & $\begin{array}{c}\text { Ukupno } \\
\text { odobrena } \\
\text { sredstva (kn) }\end{array}$ & $\begin{array}{c}\text { Broj } \\
\text { odobre- } \\
\text { nih } \\
\text { programa }\end{array}$ & $\begin{array}{c}\text { Ukupno } \\
\text { odobre- } \\
\text { nih } \\
\text { programa } \\
(\%)\end{array}$ & $\begin{array}{c}\text { Ukupno } \\
\text { odobrena } \\
\text { sredstva } \\
\text { (kn) }\end{array}$ & $\begin{array}{c}\text { Ukupno } \\
\text { odobre- } \\
\text { nih } \\
\text { sredstava } \\
(\%)\end{array}$ \\
\hline $\begin{array}{l}\text { Arhivska } \\
\text { djelatnost } \\
\text { (AD) }\end{array}$ & 954 & 36.357 .588 & 915 & 95,91 & 35.540 .058 & 97,75 \\
\hline $\begin{array}{l}\text { Međunarodna } \\
\text { kulturna } \\
\text { suradnja } \\
\text { (MKS) }\end{array}$ & 5.489 & 77.825 .509 & 31 & 0,56 & 216.320 & 0,28 \\
\hline $\begin{array}{l}\text { Digitalizacija } \\
\text { arhivske, } \\
\text { knjižnične } \\
\text { i muzejske } \\
\text { grade (DIG) }\end{array}$ & 372 & 8.374 .628 & 47 & 12,63 & 1.385 .000 & 16,54 \\
\hline $\begin{array}{l}\text { Informatizacija } \\
\text { (INF) }\end{array}$ & 792 & 9.984 .000 & 64 & 8,08 & 1.470 .000 & 14,72 \\
\hline $\begin{array}{l}\text { Investicijska } \\
\text { potpora (INV) }\end{array}$ & 1.899 & 573.200 .362 & 149 & 7,85 & 48.031 .122 & 8,38 \\
\hline $\begin{array}{l}\text { Zaštita } \\
\text { nepokretnih } \\
\text { kulturnih } \\
\text { dobara } \\
\text { (ZNKD) }\end{array}$ & 5.755 & 791.352 .025 & 3 & 0,05 & 1.232 .000 & 0,16 \\
\hline Ukupno & $\mathbf{1 5 2 6 1}$ & $\mathbf{1 . 4 9 7 . 0 9 4 . 1 1 2}$ & $\mathbf{1 2 0 9}$ & $\mathbf{7 , 9 2}$ & $\mathbf{8 7 . 8 7 4 . 5 0 0}$ & $\mathbf{5 , 8 7}$ \\
\hline
\end{tabular}

jasnije krivulje financiranja, jedan je grafikon izrađen za investicijsku potporu i arhivsku djelatnost, a drugi za preostale četiri programske djelatnosti.

Grafikon 2 i Grafikon 3 pokazuju da je u razdoblju od 2010. do 2016. prisutan kontinuirani pad ulaganja u programe arhivske djelatnosti državnih arhiva (AD). Ulaganja u 2017. i 2018. pokazuju obilježja blagoga rasta, a prema analizi Ministarstva kulture taj je rast nastavljen i u 2019. u kojoj su sredstva za programsku djelatnost državnih arhiva dodijeljena po modelu izravnoga financiranja. Dodijeljeno je 3.786 .537 kn odnosno 440.635 kn više u odnosu na 2018., 


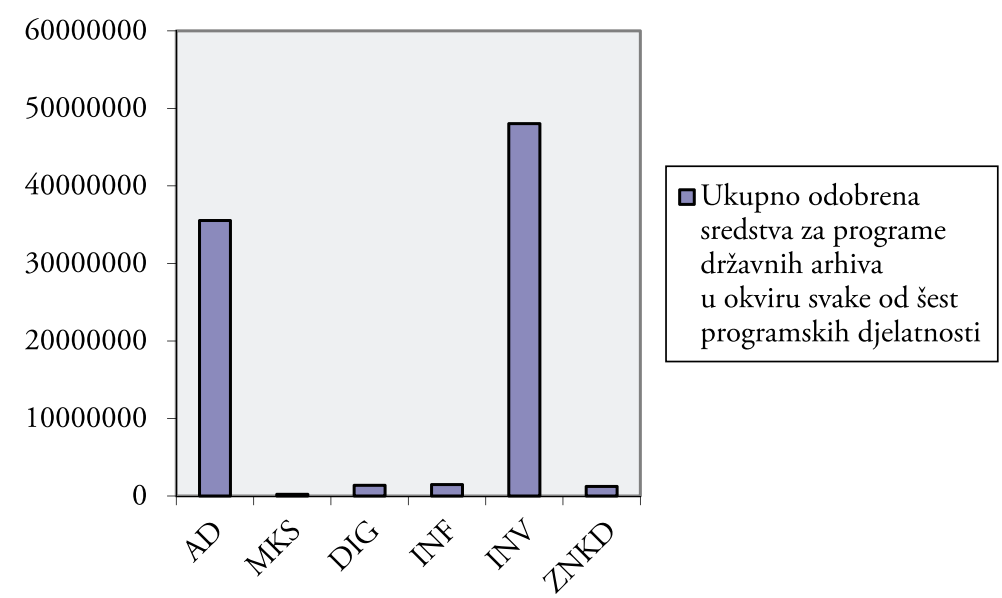

Grafikon 1. Usporedba raspodjele ukupno odobrenih sredstava za programe državnih arhiva po programskim djelatnostima od 2010. do 2018. godine.

u kojoj je dodijeljeno $3.345 .902 \mathrm{kn} .{ }^{31}$ Veće su oscilacije uočljive kod ulaganja u investicijske programe (INV). Najniža su ulaganja zabilježena u razdoblju od 2013. do 2016., s time da je unutar samoga tog razdoblja vidljiv blagi porast. Nakon znatnijega porasta u 2017., u 2018. ponovno je zabilježen pad investicijske potpore. Odobreni investicijski programi odnosili su se uglavnom na redovito održavanje, sanaciju, obnovu i izgradnju arhivskih spremišnih i radnih prostora, u što su djelomično uključeni i troškovi izrade potrebne projektne dokumentacije. Dio sredstava bio je namijenjen za nabavu opreme za spremišta (pomični regali, police, ladičari) i izvođenje protupožarnih i sigurnosnih sustava. Kod programa međunarodne kulturne suradnje (MKS) nisu evidentirane veće oscilacije, ali treba istaknuti bitniji rast u 2018. godini. Analiza podataka po godinama pokazuje da je u razdoblju 2010.-2017. državnim arhivima dodijeljeno ukupno $120.120 \mathrm{kn}$ za 22 programa međunarodne kulturne suradnje, a u 2018. za 9 takvih programa dodijeljeno je ukupno $96.200 \mathrm{kn}$. Iz toga proizlazi da sredstva za 2018. godinu čine $44,5 \%$ ukupnih sredstava odobrenih za te programe u razdoblju od 2010. do 2018. godine. Sredstva su odobravana za programe suradnje s inozemnim arhivima, organizaciju izložbi i drugih kulturnoprosvjetnih aktivnosti međunarodnoga karaktera u zemlji ili inozemstvu, sudjelovanje na programima usavršavanja te konferencijama i drugim sastancima u organizaciji međunarodnih stručnih tijela i udruženja (Europski odbor nacionalnih arhivista - EBNA, Europska arhivska grupa - EAG, Međunarodno arhivsko

\footnotetext{
31 “Odobreni programi ustanova u nadležnosti Ministarstva kulture u 2019. godini."
} 


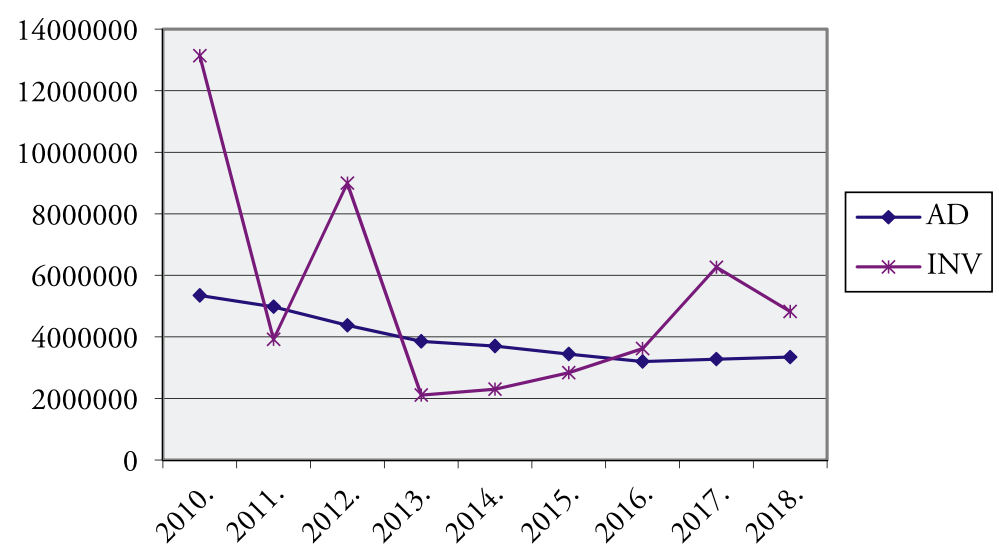

Grafikon 2. Kretanje financiranja programa arhivske djelatnosti $i$ investicijske potpore državnih arhiva od 2010. do 2018. godine

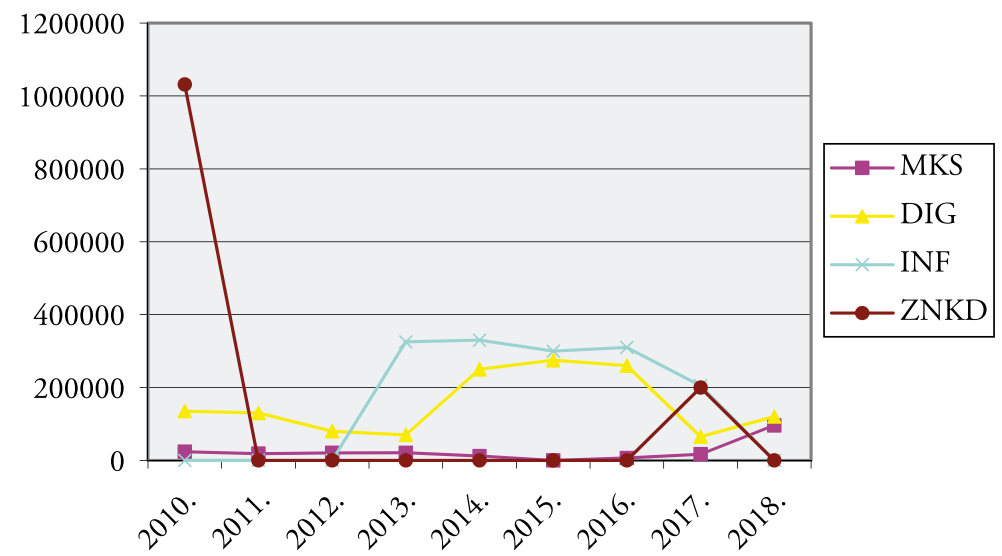

Grafikon 3. Kretanje financiranja programa medunarodne kulturne suradnje, digitalizacije, informatizacije i zaštite nepokretnih kulturnih dobara državnih arhiva od 2010. do 2018. godine

vijeće - ICA, Međunarodna konferencija okrugloga stola o arhivima - CITRA, DLM Forum). Kod programa digitalizacije (DIG) od 2010. do 2014. vidljiv je postepeni pad financiranja, a zatim se u razdoblju od 2014. do 2016. bilježi znatan porast. Može ga se objasniti time što je uz godišnje programe u tom razdoblju provođeno više trogodišnjih programa digitalizacije pojedinih državnih arhiva. Među njima se ističu dva opsežna programa (Digitalizacija gradiva o Prvom svjetskom ratu, Digitalizacija Vjesnikove novinske i fotodokumentacije) za koje je u trogodišnjem razdoblju Hrvatskomu državnomu arhivu doznačeno ukupno 450.000 
kn. Kroz pedesetak uglavnom jednogodišnjih, te nekoliko trogodišnjih programa digitalizacije, snimane su pojedine cjeline gradiva iz fundusa državnih arhiva (primjerice cehovske isprave, gradivo pavlinskih samostana, građevinska i katastarska dokumentacija, matične knjige, cjeline gradiva vezane uz obilježavanje stogodišnjice Prvoga svjetskoga rata), kako s ciljem zaštite, tako i u radi njihove bolje dostupnosti i predstavljanja korisnicima kroz razne programe ili mrežne portale. Krivulju financiranja programa informatizacije (INF) dijelom pojašnjavaju već ranije napomene da nisu dostupni podatci za razdoblje od 2010. do 2012., a da su za 2018. sredstva državnim arhivima za tu namjenu dodijeljena kroz programe investicijske potpore. Iz krivulje je vidljivo da su u razdoblju od 2013. do 2016. za te programe dodjeljivani podjednaki iznosi sredstava, uz njihovo smanjenje u 2017. godini za jednu trećinu. To potvrđuju konkretni podatci o broju programa i ukupnom iznosu sredstava na godišnjoj razini: $325.000 \mathrm{kn}$ za 13 programa u 2013 . godini, $330.000 \mathrm{kn}$ za isto toliko programa u 2014 . godini, $300.000 \mathrm{kn}$ za 14 programa u 2015. godini, $310.000 \mathrm{kn}$ za 15 programa u 2016. godini te $205.000 \mathrm{kn}$ za 9 programa u 2017. godini. Sredstva dodijeljena kroz te programe državni su arhivi koristili za programsku podršku te nabavu i održavanje računalne opreme. Kod programa zaštite na nepokretnim kulturnim dobrima (ZNKD) o krivulji financiranja može se govoriti samo uvjetno, s obzirom na to da su u cijelom razdoblju državnim arhivima odobrena tri programa u dvije godine: 2010. godine Državnomu arhivu u Osijeku odobreno je $1.000 .000 \mathrm{kn} \mathrm{za}$ program zaštite zgrade arhiva u Tvrđi te Državnomu arhivu u Varaždinu 32.000 kn za program zaštite Dvora Popovec u Velikoj Vesi (Arhivski sabirni centar Krapina), a 2017. godine Državnomu arhivu u Dubrovniku odobreno je 200.000 kn za program zaštite palače Sponza.

Opisane rezultate treba staviti u kontekst kretanja relativnoga udjela Ministarstva kulture u državnom proračunu Republike Hrvatske. Prema podatcima I. Šugar-Glavaš, taj se udio smanjio od $0,92 \%$ u 2008. godini do $0,50 \%$ u 2014. godini, uz pretpostavku da je smanjenje nastalo pod utjecajem ekonomske krize i preraspodjele sredstava državnoga proračuna prema drugim ministarstvima. U 2015. i 2016. godini zabilježen je porast udjela Ministarstva kulture u državnom proračunu Republike Hrvatske (0,63\%, odnosno 0,67\%). Unatoč blagomu padu postotnoga udjela u 2017. u odnosu na prethodnu godinu $(0,65 \%)$, proračun Ministarstva kulture porastao je u razdoblju od 2016. do 2018. za 285 milijuna kuna. Nakon rebalansa državnoga proračuna u 2018. godini, proračun je Ministarstva iznosio 1.256 milijuna kuna, što je povećanje u iznosu od 15,4\% u odnosu na 2017. godinu. ${ }^{32}$ Planirani proračun Ministarstva za 2019. iznosi 0,88\% planiranoga ukupnog državnog proračuna, a u apsolutnom iznosu bilježi rast od $2,6 \%$ u odnosu na 2018 . godinu. ${ }^{33} \mathrm{U}$ analizi o javnom

\footnotetext{
32 “Godišnje izvješće Ministarstva kulture 2018.”

33 "Analiza financiranja programa javnih potreba u kulturi u 2019. godini."
} 
financiranju kulture u zemljama članicama Europske unije u razdoblju 2007.2015., dostupnoj na mrežnim stranicama Europskoga parlamenta, također se polazi od pretpostavke da je na kretanje javnih ulaganja u kulturu na razini EU, odnosno pojedinih njezinih članica, izravno utjecala ekonomska kriza. Prema iznijetim podatcima, javna ulaganja u kulturu na razini 28 članica EU smanjena su u tom razdoblju za 3\%. Gledajući po stanovniku (per capita), zabilježeno je smanjenje od 4,77\%. U ukupnom proračunu EU, udio za kulturne programe činio je $0,73 \%$ u razdoblju od 2007 . do 2013 ., odnosno $0,71 \%$ u razdoblju od 2014. do 2020. godine. U financijskoj perspektivi EU za razdoblje od 2021. do 2027. godine priželjkuje se povećanje tog udjela na $1 \% .^{34}$

Analiza raspodjele ukupno odobrenih sredstava među državnim arhivima pokazuje da su tri najveća korisnika programskih sredstava Hrvatski državni arhiv $(32,05 \%)$, Državni arhiv u Dubrovniku $(18,36 \%)$ i Državni arhiv u Zagrebu $(6,16 \%)$. Svi ostali arhivi ostvarili su udjele manje od 5\%. Od toga, njih je pet ostvarilo udjele veće od 4\% (Zadar, Varaždin, Osijek, Šibenik, Rijeka), a Hrvatski memorijalno-dokumentacijski centar Domovinskog rata ostvario je udio od 3,6\%. Šest arhiva ostvarilo je udjele između 2\% i 3\% (Vukovar, Međimurje Štrigova, Karlovac, Pazin, Slavonski Brod, Split). Državni arhiv u Virovitici ostvario je udio od $1,25 \%$, a udio manji od $1 \%$ ostvarili su državni arhivi u Gospiću (0,95\%), Sisku (0,96\%) i Bjelovaru (0,42\%). Takvu raspodjelu ilustrira Grafikon 4, a u Tablici 2 navedeni su detaljniji podatci o sredstvima dodijeljenim arhivima ukupno i po programskim djelatnostima. Opisane rezultate treba staviti u kontekst specifičnih mogućnosti svakoga pojedinog državnog arhiva, koje velikim dijelom proizlaze iz njihovih raspoloživih prostornih (spremišta, prostori za rad i njihova opremljenost) i ljudskih resursa (broj zaposlenih djelatnika i njihove stručne kompetencije). Primjer Državnoga arhiva u Bjelovaru vjerojatno najbolje ilustrira poteškoće koje pojedini državni arhivi imaju s raspoloživim prostornim kapacitetima. Iako djeluje od 1961. godine, taj Arhiv u 2019. godini ne posjeduje vlastite prostore, nego je u najmu radnoga i spremišnoga prostora na tri različite lokacije u gradu Bjelovaru. ${ }^{35}$ Razlike među državnim arhivima u pogledu raspoloživih ljudskih resursa ilustriraju sljedeći podatci. Krajem 2016. godine u 18 državnih arhiva bilo je ukupno 486 zaposlenih. Od toga, četiri su arhiva imala manje do 10 zaposlenih (Virovitica, Vukovar, Međimurje - Štrigova, Šibenik), četiri arhiva između 10 i 17 zaposlenih (Sisak, Gospić, Bjelovar, Slavonski Brod),

\footnotetext{
34 Pere Almeda, Albert Sagarra i Marc Tataret, "Public spending on culture in Europe 2007-2015," European Parliament, pristupljeno 2. svibnja 2019., http://www.europarl.europa.eu/cmsdata/139228/ ALMEDA_Public\%20spending\%20on\%20culture\%202007-2015\%20-\%2021F\%20-\%20EP\%20 -Cuture\%20Commission\%2021\%20FEB.pdf, str. 4 i 10. Usp. Vesna Čopič i dr., "Trends in Public Funding for Culture in the EU (EENC Report, August 2013, Revised July 2014)," European Expert Network on Culture (EENC), pristupljeno 2. svibnja 2019., http://www.interarts.net/descargas/interarts2573.pdf.

35 "Plan rada za 2019. godinu, Bjelovar, srpanj 2018.," Državni arhiv u Bjelovaru, pristupljeno 28. ožujka 2019., http://www.dabj.hr/dok/Plan\%20rada\%20u\%202019.\%20godini.pdf.
} 


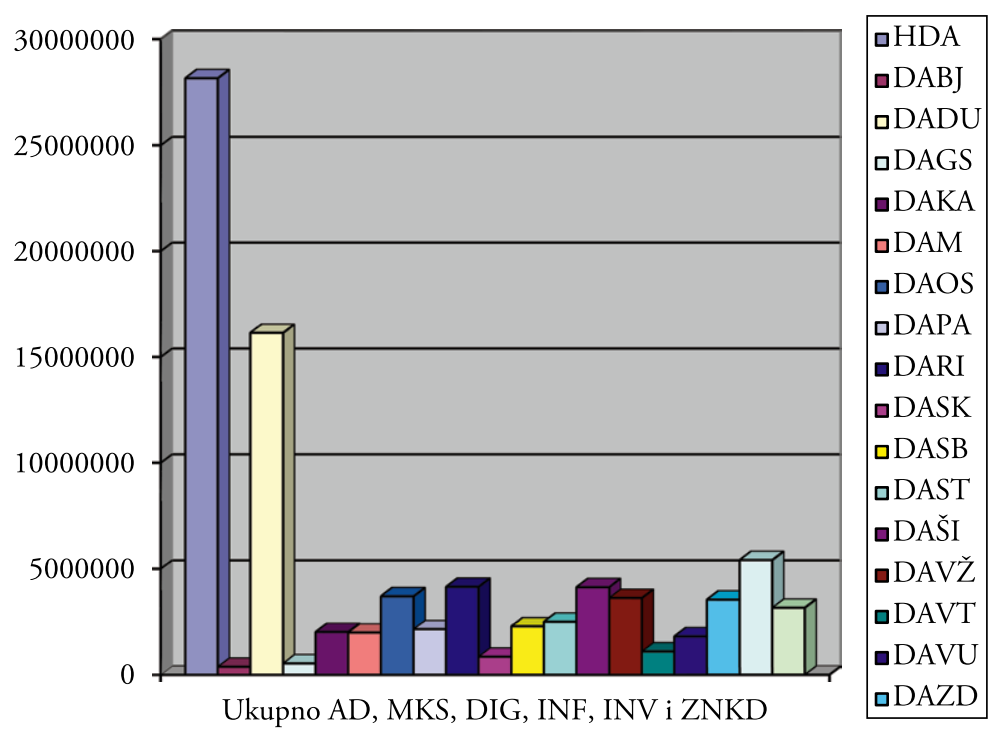

Grafikon 4. Usporedba raspodjele ukupno odobrenih programskih sredstava državnim arhivima od 2010. do 2018. godine

šest arhiva između 21 i 28 zaposlenih (Karlovac, Osijek, Varaždin, Split, Rijeka, Pazin), tri državna arhiva više od 30 zaposlenih (Zadar, Dubrovnik, Zagreb), a u Hrvatskom državnom arhivu bilo je zaposleno 159 osoba. ${ }^{36}$ Navedeno je zasigurno imalo utjecaja na raznovrsnost i broj programa koje su državni arhivi prijavljivali za financiranje u okviru javnih potreba u kulturi Republike Hrvatske (Grafikon 5). Osim toga, neujednačenost među državnim arhivima u pogledu broja odobrenih programa i iznosa sredstava za njihovu realizaciju zasigurno proizlazi i iz nedostatka dugoročnoga planiranja i strategije razvoja na razini hrvatske arhivske službe u cjelini. Pozitivne pomake u tom dijelu trebala bi donijeti izrada već spomenutoga Nacionalnog plana razvoja arhivske djelatnosti za razdoblje 2020.-2030.

Kao što je vidljivo iz Grafikona 4, Grafikona 5 i Tablice 2, veći udio u broju odobrenih programa ne podrazumijeva nužno i veći udio u iznosu odobrenih sredstava i obratno. Primjerice, iako ima drugi najveći udjel odobrenih sredstava $(18,36 \%)$, Državni arhiv u Dubrovniku deseti je po udjelu u ukupnom broju odobrenih programa (4,47\%). Državni arhiv u Osijeku i Hrvatski memorijalno-dokumentacijski centar Domovinskog rata, koji imaju drugi i treći najveći udjel u broju odobrenih programa $(8,11 \%$ i $6,45 \%)$, šesti su, odnosno deveti

36 Hrvatski državni arhiv, Odsjek za matičnu, razvojnu i dokumentacijsku službu, Evidencija zaposlenih u državnim arhivima. 


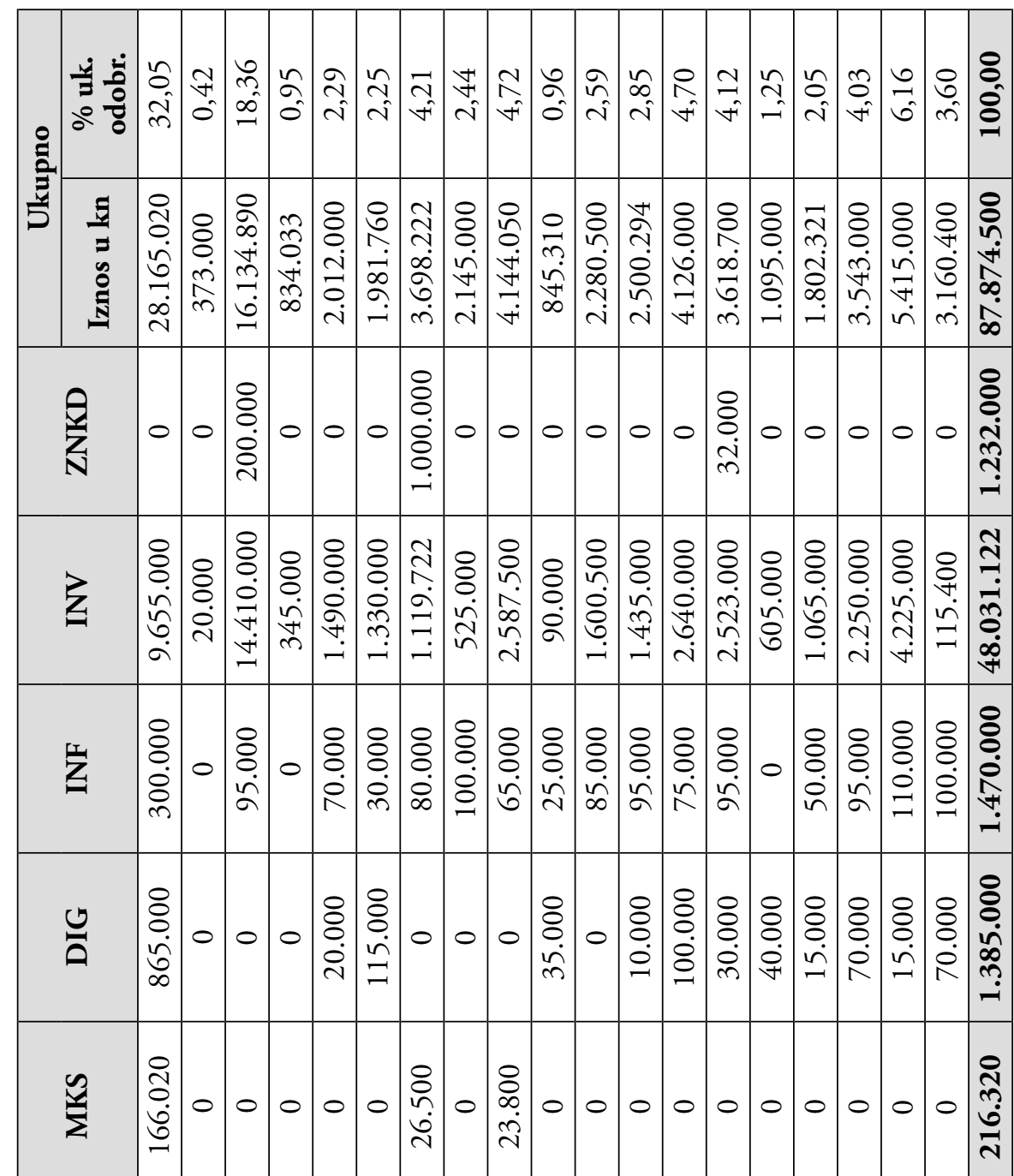

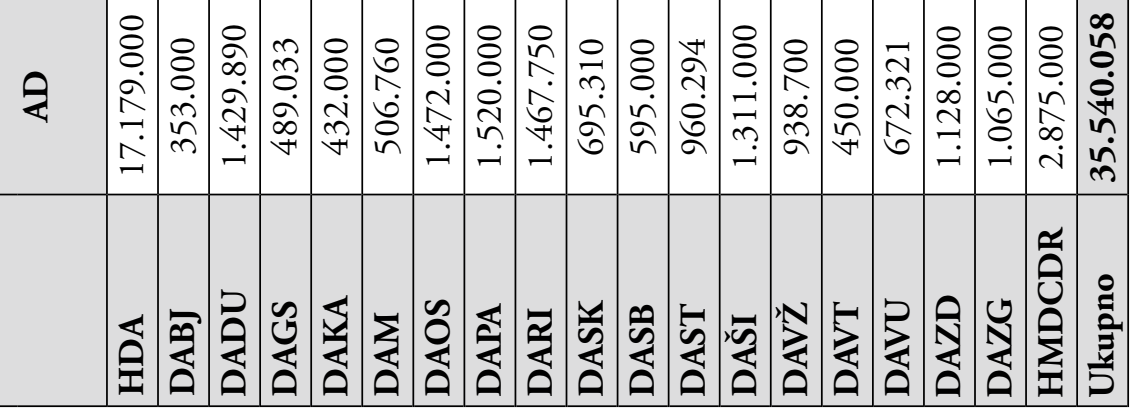




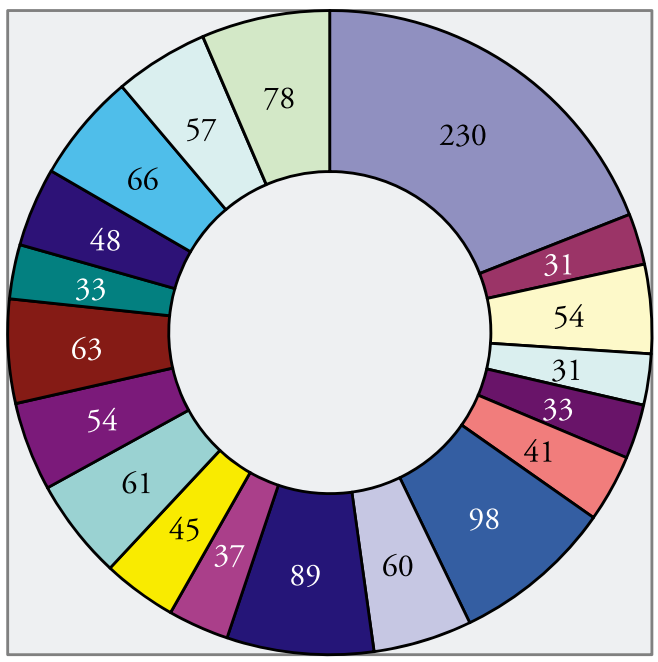

\begin{tabular}{|c|}
\hline$\square \mathrm{HDA}$ \\
\hline$\square \mathrm{DABJ}$ \\
\hline$\square \mathrm{DADU}$ \\
\hline 口DAGS \\
\hline$\square \mathrm{DAKA}$ \\
\hline 口DAM \\
\hline 口DAOS \\
\hline 口DAPA \\
\hline -DARI \\
\hline DAASK \\
\hline$\square \mathrm{DASB}$ \\
\hline 口DAST \\
\hline 口DAŠI \\
\hline 口DAVŽ \\
\hline
\end{tabular}

Grafikon 5. Usporedba državnih arhiva prema broju odobrenih programa javnih potreba u kulturi RH od 2010. do 2018. godine

po udjelu odobrenih sredstava (4,21\% i 3,6\%). Razlog je tomu različit pristup arhivâ prilikom prijave posebnih programa, kao i metodologija prijave, odnosno dodjele sredstava unutar pojedinih programskih djelatnosti. Konkretno, unutar arhivske djelatnosti dio je državnih arhiva objedinjavao srodne aktivnosti u jedan program, a dio njih formulirao ih je kao više samostalnih programa (primjerice više izložbi ili izdanja kao samostalni programi ili izložbena i izdavačka djelatnost kao samo dva programa). Unutar programa investicijske potpore prijavljivan je manji broj programa za koje su dodjeljivani veći iznosi sredstava. To potvrđuju i sljedeći podatci: iznos od 48.031.122 kn raspodijeljen je državnim arhivima za 149 programa investicijske potpore, a iznos od $35.540 .058 \mathrm{kn}$ raspodijeljen je za čak 915 programa arhivske djelatnosti.

U analizi financiranja na prethodnim stranicama već je opisana konkretna namjena sredstava odobrenih kroz programe međunarodne kulturne suradnje, digitalizacije, informatizacije, investicijske potpore i zaštite na nepokretnim kulturnim dobrima. U nastavku slijedi detaljnija analiza programa državnih arhiva odobrenih u okviru arhivske djelatnosti, s obzirom na to da čine 95,91\% svih odobrenih programa, odnosno 97,75\% ukupno odobrenih sredstava u okviru te djelatnosti (Tablica 1). Iz takve je analize vidljivo na koje su vrste aktivnosti, u kojem opsegu i u kojem kontinuitetu (kratkoročno i dugoročno) državni arhivi stavljali naglasak, te u kojoj su mjeri one bile podudarne s njiho- 
vim osnovnim zadaćama. $S$ tim ciljem, 915 odobrenih pojedinačnih programa grupirano je u pet potprogramskih djelatnosti, prema smjernicama koje su bile utvrđene za prijavu programa za 2018. godinu: zaštita arhivskoga gradiva, prikupljanje (otkup) arhivskoga gradiva, izdavačka djelatnost, izložbena i promotivna djelatnost (kulturne manifestacije) te znanstvena djelatnost, stručno usavršavanje i razvoj. Unutar zaštite arhivskoga gradiva sabrani su svi pojedinačni programi koji se odnose na konzervaciju i restauraciju gradiva, zaštitno snimanje (mikrofilmiranje, digitalizacija), nabavu zaštitne opreme (arhivske kutije, mape, posebne vrste papira), evidentiranje te projektnu obradu i opis gradiva. Raspodjela sredstava unutar tih pet potprogramskih djelatnosti prikazana je grafikonom u nastavku.

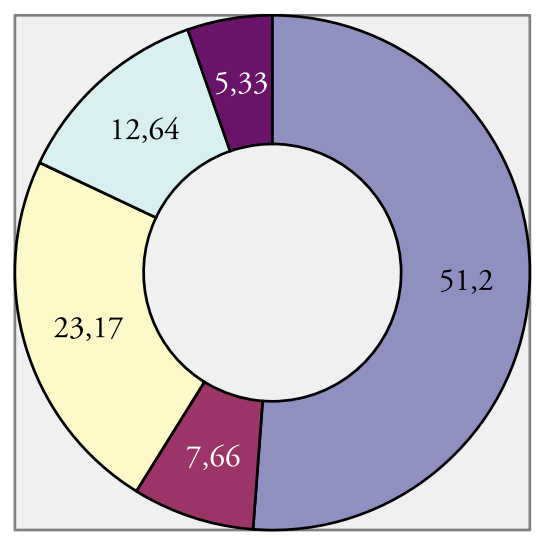

$\square$ Zaštita

$\square$ Prikupljanje (otkup)

口Izdavačka djelatnost

口Izložbena i promotivna djelatnost

$\square$ Znanstvena djelatnost, stručno usavršavanje i razvoj

Grafikon 6. Usporedba raspodjele sredstava za programe arhivske djelatnosti državnih arhiva po potprogramskim djelatnostima od 2010. do 2018. godine (u postotcima)

Gledajući ukupno sve arhive, natpolovični udjel sredstava (51,2\%) odnosio se na programe fizičko-tehničke i intelektualne zaštite arhivskoga gradiva. Ukupno $23,17 \%$ iznosa sredstava utrošeno je na programe izdavačke djelatnosti (arhivistički časopisi, objava arhivskih izvora - zbirke dokumenata, zbornici stručno-znanstvenih skupova, stručni priručnici, druge publikacije). Znatan udio sredstava $(12,64 \%)$ odnosi se na programe izložbi, promocija, drugih kulturnih manifestacija i drugih sadržaja namijenjenih široj javnosti putem kojih se nastoji povećati interes za arhive $\mathrm{i}$ arhivsko gradivo kao dio kulturne baštine, te povećati krug korisnika usluga arhiva. Na prikupljanje (otkup) arhivskoga gradiva odnosilo se 7,66\%, a na znanstvenu djelatnost, stručno usavršavanje i razvoj 5,33\% odobrenih sredstava. Detaljniji podatci o odobrenim iznosima po potprogram- 
skim djelatnostima (ukupno, za svaki državni arhiv) navedeni su u nastavku (Tablica 3).

Tablica 3. Pregled iznosa sredstava odobrenih državnih arhivima za programe arhivske djelatnosti po potprogramskim djelatnostima od 2010. do 2018. godine

\begin{tabular}{|l|l|l|l|l|l|l|}
\hline & $\begin{array}{l}\text { Zaštita } \\
\text { arhivskoga } \\
\text { gradiva }\end{array}$ & $\begin{array}{l}\text { Prikup- } \\
\text { ljanje } \\
\text { (otkup) } \\
\text { arhivskoga } \\
\text { gradiva }\end{array}$ & $\begin{array}{l}\text { Izdavačka } \\
\text { djelatnost }\end{array}$ & $\begin{array}{l}\text { Izložbena } \\
\text { i promo- } \\
\text { tivna } \\
\text { djelatnost }\end{array}$ & $\begin{array}{l}\text { Znanstvena } \\
\text { djelatnost, } \\
\text { stručno } \\
\text { usavršava- } \\
\text { nje i razvoj }\end{array}$ & Ukupno \\
\hline HDA & 10.129 .000 & 1.700 .000 & 2.560 .000 & 1.185 .000 & 1.605 .000 & 17.179 .000 \\
\hline DABJ & 178.000 & 0 & 65.000 & 110.000 & 0 & 353.000 \\
\hline DADU & 1.221 .510 & 20.000 & 185.000 & 3.380 & 0 & 1.429 .890 \\
\hline DAGS & 318.033 & 0 & 95.000 & 76.000 & 0 & 489.033 \\
\hline DAKA & 340.000 & 0 & 88.500 & 3.500 & 0 & 432.000 \\
\hline DAM & 310.760 & 0 & 60.000 & 136.000 & 0 & 506.760 \\
\hline DAOS & 465.000 & 0 & 644.000 & 323.000 & 40.000 & 1.472 .000 \\
\hline DAPA & 560.000 & 0 & 790.000 & 140.000 & 30.000 & 1.520 .000 \\
\hline DARI & 765.000 & 60.750 & 415.000 & 191.000 & 36.000 & 1.467 .750 \\
\hline DASK & 272.000 & 44.610 & 75.000 & 303.700 & 0 & 695.310 \\
\hline DASB & 333.000 & 0 & 85.000 & 177.000 & 0 & 595.000 \\
\hline DAST & 448.294 & 30.000 & 292.000 & 170.000 & 20.000 & 960.294 \\
\hline DAŠI & 634.000 & 50.000 & 310.000 & 277.000 & 40.000 & 1.311 .000 \\
\hline DAVŽ & 227.000 & 51.700 & 330.000 & 330.000 & 0 & 938.700 \\
\hline DAVT & 80.000 & 60.000 & 160.000 & 125.000 & 25.000 & 450.000 \\
\hline DAVU & 165.000 & 20.000 & 339.189 & 113.132 & 35.000 & 672.321 \\
\hline DAZD & 508.000 & 0 & 295.000 & 280.000 & 45.000 & 1.128 .000 \\
\hline DAZG & 610.000 & 0 & 205.000 & 230.000 & 20.000 & 1.065 .000 \\
\hline HMDCDR & 630.000 & 685.000 & 1.240 .000 & 320.000 & 0 & 2.875 .000 \\
\hline Ukupno & $\mathbf{1 8 . 1 9 4 . 5 9 7}$ & $\mathbf{2 . 7 2 2 . 0 6 0}$ & $\mathbf{8 . 2 3 3 . 6 8 9}$ & 4.493 .712 & $\mathbf{1 . 8 9 6 . 0 0 0}$ & $\mathbf{3 5 . 5 4 0 . 0 5 8}$ \\
\hline & & & & & & \\
\hline
\end{tabular}

Opisane programske aktivnosti državnih arhiva dobrim su dijelom podudarne s aktivnostima čije se financiranje potiče na razini Europske unije. U višegodišnjem financijskom okviru EU za razdoblje 2014.-2020. više je programa unutar kojih je moguće prijaviti sufinanciranje projekata na području kulture. U kontekstu državnih arhiva posebno treba izdvojiti dva programa: Kreativna Europa i Operativni program Konkurentnost i kohezija. Oba programa treba staviti u kontekst strateških dokumenata EU (Strategija Europa 2020, Digitalna 
agenda za Europu) koji predviđaju niz inicijativa za rast i zapošljavanje. Između ostaloga, nastoji se potaknuti europsko gospodarstvo osiguranjem održivih gospodarskih i socijalnih pogodnosti jedinstvenoga digitalnoga tržišta, uključivo i putem mrežne ponude kulturnih sadržaja. ${ }^{37}$ Program Kreativna Europa (2014.2020.) koji provodi Europska komisija, odnosno Izvršna agencija za obrazovanje, audiovizualnu djelatnost i kulturu potpora je europskoj kinematografiji te kulturnomu i kreativnomu sektoru s ciljem njihova doprinosa održivom rastu i zapošljavanju. Čine ga dva zasebna potprograma Kultura i MEDIA. ${ }^{38} \mathrm{U}$ okviru financiranja javnih potreba u kulturi RH, Ministarstvo kulture posebnim je Pravilnikom odredilo kriterije i postupak prema kojima će sufinancirati projekte pravnih osoba odobrene unutar toga programa. ${ }^{39}$ Kao primjer dobre prakse u okviru programa Kreativna Europa može se izdvojiti četverogodišnji projekt (1. prosinca 2014. - 30. studenoga 2018.) Community as Opportunity: The creative Archives' and Users' network ('Zajednica kao prilika: Kreativna arhivska i korisnička mreža”), koji je na čelu s Arhivom Države Hessen u Marburgu (Hessischen Staatsarchivs Marburg) provodilo sedamnaest ustanova iz jedanaest europskih zemalja. Kao partner na projektu, Hrvatski je državni arhiv bio nositelj jednoga radnog paketa te organizator završnoga festivala, odnosno konferencije u studenom 2018. godine. Kroz stvaranje Topoteka, galerija digitalnih sadržaja povezanih s određenim zemljopisnim područjem, u projektne se aktivnosti uključilo i više područnih državnih arhiva. ${ }^{40} \mathrm{U}$ sklopu Operativnoga programa Konkurentnost i kohezija (2014.-2020.), prioritetne osi 2, predviđeno je sufinanciranje aktivnosti koje pridonose poboljšanju dostupnosti, korištenja i kvalitete informacijskih i komunikacijskih tehnologija, uključujući i razvoj e-kulture. ${ }^{41} \mathrm{U}$ okviru toga programa, Ministarstvo je kulture prijavilo za financiranje i predvidjelo za provedbu na nacionalnoj razini projekt e-Kultura: Digitalizacija kulturne baštine. ${ }^{42}$

37 Usp. "Izvješće o analizi trenutnog stanja, Ernst \& Young Savjetovanje d.o.o., ožujak 2018. godine," Ministarstvo kulture Republike Hrvatske, pristupljeno 2. svibnja 2019., https://www.min-kulture.hr/ default.aspx?id=19948.

38 "Program Europske unije - Kreativna Europa," Ministarstvo kulture Republike Hrvatske, pristupljeno 2. svibnja 2019., https://www.min-kulture.hr/ced/.

39 Usp. Pravilnik o sufinanciranju projekata odobrenih u okviru programa Europske unije Kreativna Europa - potprogram Kultura, NN 146/2014; Pravilnik o izmjeni Pravilnika o sufinanciranju projekata odobrenih u okviru programa Europske unije Kreativna Europa - potprogram Kultura, NN 110/2016; Pravilnik o sufinanciranju projekata odobrenih u okviru programa Europske unije Kreativna Europa potprogram Kultura, NN 45/2018.

40 “Co:op," Hrvatski državni arhiv, pristupljeno 2. svibnja 2019., http://www.arhiv.hr/Projekti-i-aktivnosti/coop.

41 "Operativni program Konkurentnost i kohezija 2014. - 2020., Hrvatski prijevod s engleskog, Zagreb, studeni 2018.," Europski strukturni i investicijski fondovi, pristupljeno 2. svibnja 2019., https:// strukturnifondovi.hr/wp-content/uploads/2019/02/OPKK_070219.pdf.

${ }_{42}$ "Digitalizacija kulturne baštine," Ministarstvo kulture Republike Hrvatske, pristupljeno 2. svibnja 2019., https://www.min-kulture.hr/default.aspx?id=9943. 
Podudarnost programskih aktivnosti hrvatskih državnih arhiva uočljiva je i kod usporedbe s programima razvijenih arhivskih službi izvan Europe, primjerice australskom i kanadskom. U strateškim dokumentima Nacionalnoga arhiva Australije za razdoblje 2018.-2022. postavljena su tri cilja: podrška državnim tijelima u upravljanju dokumentacijom u kontekstu digitalizacije poslovanja odnosno uvođenja e-uprave (Digital Continuity 2020 Policy); poduzimanje mjera za zaštitu i očuvanje arhivskoga gradiva od nacionalnoga interesa, uključujući digitalizaciju zbirki, povećanje sposobnosti digitalnoga arhiviranja, brži razvoj digitalnih vještina i procesa, te unaprjeđenje mjera fizičko-tehničke zaštite gradiva u arhivu; povezivanje istraživača i šire društvene zajednice $s$ arhivom $s$ ciljem poticanja boljega razumijevanja društvene uloge arhiva. ${ }^{43} \mathrm{U}$ skladu $s$ tim ciljevima planirana su i sredstva u državnom proračunu za razdoblje 2019.-2020. U odnosu na ranije razdoblje, za izdvojiti je planirano povećanje dotacija iz državnoga proračuna za projekt uređenja spremišnoga prostora kapaciteta 75.000 $\mathrm{d} / \mathrm{m}$ te digitalizaciju gradiva ureda premijera. ${ }^{44} \mathrm{Na}$ sličan su način postavljeni i strateški ciljevi Knjižnice i arhiva Kanade za razdoblje od 2019. do 2022. godine. Između ostaloga, odnose se na daljnju digitalnu transformaciju poslovanja ustanove, povećanje dostupnosti gradiva korisnicima posredstvom novih tehnologija, obogaćivanje fondova i zbirki novim konvencionalnim i digitalnim sadržajima provedbom petogodišnje akvizicijske strategije (2019.-2024.) te poboljšanje uvjeta fizičko-tehničke i intelektualne zaštite. Tako je primjerice planirano ulaganje od oko 35 milijuna dolara u izgradnju novoga spremišta za konvencionalno gradivo u Quebecu (Gatineau 2 Preservation Facility). ${ }^{45}$

\section{Zaključak}

Kao zasebnu programsku djelatnost (kategoriju), arhivsku djelatnost nalazimo u svim godišnjim javnim Pozivima za financiranje programa javnih potreba u kulturi Republike Hrvatske u proteklom desetogodišnjem razdoblju. Uz to, pojedinačni su programi državnih arhiva podudarni i s nekoliko drugih programskih djelatnosti uvrštenih u godišnje programe javnih potreba u kulturi,

\footnotetext{
43 "National Archives of Australia Corporate Plan 2018-19 to 2021-22," National Archives of Australia, pristupljeno 2. svibnja 2019., http://www.naa.gov.au/about-us/organisation/accountability/corporateplan/2018-19-to-2021-22.aspx; "Digital Continuity 2020 Policy," National Archives of Australia, pristupljeno 2. svibnja 2019., http://www.naa.gov.au/information-management/digital-transition-anddigital-continuity/digital-continuity-2020/index.aspx.

44 "Budget 2019-20," Australian Government, Attorney-General's Department, pristupljeno 2. svibnja 2019., https://www.ag.gov.au/Publications/Budgets/Budget2019-20/Pages/Portfolio-Budget-Statements2019-20.aspx.

45 Usp. “Departmental Plan 2019-2020," Library and Archives Canada, pristupljeno 2. svibnja 2019., http://www.bac-lac.gc.ca/eng/about-us/report-plans-priorities/departmental-plan-2019-2020/Pages/ departmental-plan-2019-2020.aspx; "Gatineau 2 Preservation Facility," Library and Archives Canada, pristupljeno 2. svibnja 2019., https://www.bac-lac.gc.ca/eng/about-us/preservation/Pages/gatineau-2.aspx.
} 
poput međunarodne kulturne suradnje, informatizacije, digitalizacije, investicijske potpore te zaštite nepokretnih kulturnih dobara, s obzirom da pojedini arhivi kao spremišne ili radne prostore koriste zgrade koje imaju taj status. Iz toga proizlazi da su arhivski programi prepoznati kao dio kulturnih djelatnosti i poslova, odnosno akcija i manifestacija u kulturi od interesa za državu. Kao što je detaljnije opisano u članku, u šest spomenutih programskih djelatnosti državnim je arhivima u razdoblju 2010.-2018. odobreno 1.209 programa ukupne vrijednosti $87.874 .500 \mathrm{kn}$. To čini $5,87 \%$ ukupno odobrenoga iznosa sredstava za te programske djelatnosti. Gledajući prosječna godišnja ulaganja iz proračuna Ministarstva kulture u sve kulturne djelatnosti, projekte, programe i potpore, prosječna godišnja ulaganja u programe državnih arhiva iznosila su 3,43\%. Stvarna ulaganja na godišnjoj razini ovisila su o udjelu Ministarstva kulture u ukupnom državnom proračunu RH. Nakon višegodišnjega pada ulaganja koji je najvjerojatnije nastao pod utjecajem ekonomske krize i preraspodjele sredstava državnoga proračuna prema drugim resorima, od 2017. vidljiv je rast ulaganja u arhivske programe. Pozitivne učinke na razvoj arhivske službe i rad državnih arhiva zasigurno bi imalo održavanje trenda rasta ulaganja u arhivske programe, odnosno programe kulturnih djelatnosti u cjelini. Na tragu toga priželjkuje se porast udjela Ministarstva kulture u ukupnom državnom proračunu RH na $1 \%$.

Analiza raspodjele ukupno odobrenih sredstava među državnim arhivima pokazuje da su tri najveća korisnika programskih sredstava bili Hrvatski državni arhiv (32,05\%), Državni arhiv u Dubrovniku (18,36\%) i Državni arhiv u Zagrebu (6,16\%). Svi ostali arhivi ostvarili su udjele manje od 5\%. Ti pokazatelji ilustriraju neujednačenost među državnim arhivima u pogledu broja i raznovrsnosti prijavljenih programa. Takva neujednačenost proizlazi iz specifičnih mogućnosti svakoga pojedinog državnog arhiva (ponajprije u pogledu raspoloživih prostornih i ljudskih resursa), ali i iz nedostatka dugoročnoga planiranja i strategije razvoja na razini hrvatske arhivske službe u cjelini. Pozitivne pomake u tom dijelu trebala bi donijeti izrada Nacionalnoga plana razvoja arhivske djelatnosti za razdoblje 2020.-2030. Konkretno, za očekivati je da će se tim dokumentom utvrditi konkretni programi razvoja arhivske djelatnosti koje će kao nositelji ili dionici, koordinirano i bez iznimke, provoditi svi državni arhivi. Za svaki od programa i njime predviđenih provedbenih aktivnosti očekuje se projekcija potrebnih financijskih sredstava i konkretnih izvora financiranja (primjerice državni proračun, sredstva jedinica lokalne i područne (regionalne) samouprave, EU fondovi, drugi izvori financiranja). Posebno je važno utvrditi i vremensku dinamiku te konkretne pokazatelje na temelju kojih će biti moguće pratiti stvarni napredak u provedbi planiranoga.

Prema namjeni, oko 58\% ukupnih sredstva odobrenih državnim arhivima kroz programe javnih potreba u kulturi $\mathrm{RH}$ odnosilo se na infrastrukturne programe, kao što su uređenje spremišnih i radnih prostora, nabava informatičke i druge opreme, te postavljanje sigurnosnih sustava na zgradama. To je bitan pre- 
duvjet da bi državni arhivi kao javne ustanove uopće mogli redovito funkcionirati. Ostatak sredstava odnosio se na programe usmjerene na poboljšanje fizičkotehničke i intelektualne zaštite gradiva u arhivima, prikupljanje gradiva koje se ne preuzima po službenoj dužnosti, suradnju sa ustanovama i udruženjima u zemlji i inozemstvu, izdavačku djelatnost, istraživačke projekte, izložbe i druge kulturne manifestacije, te druge sadržaje namijenjene korisnicima gradiva i široj javnosti. Iz toga je vidljivo da su "posebni" arhivski programi u biti bili usmjereni na obavljanje i razvoj osnovnih, zakonom propisanih zadaća arhiva. U tom smislu, čini se opravdanom promjena modela financiranja državnih arhiva uvedena 2018. godine, prema kojoj se troškovi programske djelatnosti planiraju i ugovaraju zajedno s ostalim troškovima (materijalni izdatci i plaće) koje Ministarstvo kulture osigurava državnim arhivima po osnovi obavljanja osnivačkih prava.

Iako opseg ovoga članka ne dopušta opširniju analizu u tom smjeru, treba naglasiti zadaću državnih arhiva da osim iz državnoga proračuna sredstva za svoje programe osiguraju i iz drugih izvora. Uz uvodno spomenute vlastite prihode, sponzorstva, donacije, korištenje zajedničkih resursa i slično, mogućnost za znatniji iskorak postoji na području korištenja sredstava iz EU fondova, odnosno boljega pozicioniranja arhivske i drugih kulturnih djelatnosti u financijskoj perspektivi EU za razdoblje od 2021. do 2027. godine. Također, arhivski programi mogu i trebaju biti takvi da njihovi rezultati (proizvodi i usluge) čine nove resurse, u smislu potencijalnih izvora novih prihoda. Prema prijedlogu koji je Europska komisija predstavila 2. svibnja 2018., proračun Europske unije za razdoblje od 2021. do 2027., umjesto dosadašnjih pet, imat će sedam poglavlja: 1 . jedinstveno tržište, inovacije i digitalno gospodarstvo; 2 . kohezija i vrijednosti; 3 . prirodni resursi i okoliš; 4. migracije i upravljanje granicama; 5. sigurnost i obrana; 6. susjedstvo i svijet; 7. europska javna uprava. ${ }^{46}$ Prema dostupnim podatcima, čini se da će primarni izvori financiranja projekata državnih arhiva biti programi Digitalna Europa 2021.-2027. i Kreativna Europa 2021.-2027. Jedan od pet posebnih ciljeva programa Digitalna Europa odnosi se na »uvođenje, najbolju uporabu digitalnih kapaciteta $\mathrm{i}$ interoperabilnost« na području modernizacije javnih uprava, zdravstva, pravosudnoga sustava, prometa, mobilnosti, energije i okoliša, te obrazovanja, kulture i medija. Između ostaloga, predviđa se da će učinci programa biti: pružanje pristupa najnovijim digitalnim tehnologijama (od umjetne inteligencije do naprednoga računalstva) autorima, kreativnoj industriji i kulturnom sektoru u Europi; uporaba europske kulturne baštine, uključujući inicijativu Europeana, $s$ ciljem podupiranja obrazovanja i istraživanja te promicanja kulturne raznolikosti, socijalne kohezije i europskoga društva; prihvaćanje digitalnih tehnologija u obrazovanju te privatno i javno financiranim kulturnim institucijama. U sinergiji s programom Kreativna Europa, očekivani su učinci za

46 Daniel Mondekar, "Javne politike na razini Europske unije za financijsku perspektivu 2021. - 2027. godine: izazovi, obveze i prilike," EU-Projekti.info, pristupljeno 2. svibnja 2019., https://www.eu-projekti.info/eu/wp-content/uploads/2019/02/4_Daniel-Mondekar.pdf. 
kulturni i kreativni sektor Europe pristup najnovijim digitalnim tehnologijama i prilagodba digitalnim transformacijama, a u sinergiji s drugim programima i inicijativama EU-a očekuju se učinci u pogledu kompetencija, odnosno vještina. ${ }^{47}$

\section{POPIS IZVORA}

\section{Arhivsko gradivo}

\section{Hrvatski državni arhiv}

Odsjek za matičnu, razvojnu i dokumentacijsku službu.

Pismohrana.

\section{Službena glasila i tisak}

Narodne novine (Zagreb), 1990, 1993, 1997, 2001, 2004, 2006, 20082009, 2012-2018.

\section{Literatura}

"Analiza financiranja programa javnih potreba u kulturi u 2019. godini." Ministarstvo kulture Republike Hrvatske. Pristupljeno 13. ožujka 2019. https:// www.min-kulture.hr/default.aspx?id=19563.

"Budget 2019-20." Australian Government, Attorney-General's Department. Pristupljeno 2. svibnja 2019. https://www.ag.gov.au/Publications/Budgets/ Budget2019-20/Pages/Portfolio-Budget-Statements-2019-20.aspx.

“Co:op." Hrvatski državni arhiv. Pristupljeno 2. svibnja 2019. http:// www.arhiv.hr/Projekti-i-aktivnosti/coop.

"Departmental Plan 2019-2020." Library and Archives Canada. Pristupljeno 2. svibnja 2019. http://www.bac-lac.gc.ca/eng/about-us/report-plans-priorities/departmental-plan-2019-2020/Pages/departmental-plan-2019-2020.aspx.

"Digital Continuity 2020 Policy." National Archives of Australia. Pristupljeno 2. svibnja 2019. http://www.naa.gov.au/information-management/digital-transition-and-digital-continuity/digital-continuity-2020/index.aspx.

\footnotetext{
47 “Program Digitalna Europa za razdoblje 2021.-2027.," Europski parlament, pristupljeno 2. svibnja 2019., http://www.europarl.europa.eu/doceo/document/TA-8-2019-0403_HR.html\#title2; "Kreativna Europa: Vijeće postiglo dogovor o stajalištu u vezi s programom za razdoblje 2021. - 2027.," Europsko vijeće, Vijéce Europske unije, pristupljeno 2. svibnja 2019., https://www.consilium.europa.eu/ $\mathrm{hr} /$ press/press-releases/2018/12/20/creative-europe-council-agrees-its-position-on-the-programme-for2021-2027/.
} 
"Digitalizacija kulturne baštine." Ministarstvo kulture Republike Hrvatske. Pristupljeno 2. svibnja 2019. https://www.min-kulture.hr/default.aspx?id=9943.

"Financiranje." Ministarstvo kulture Republike Hrvatske. Pristupljeno 21. ožujka 2019. https://www.min-kulture.hr/default.aspx?id=2570.

"Gatineau 2 Preservation Facility." Library and Archives Canada. Pristupljeno 2. svibnja 2019. https://www.bac-lac.gc.ca/eng/about-us/preservation/ Pages/gatineau-2.aspx.

“Godišnje izvješće Ministarstva kulture 2018.” Ministarstvo kulture Republike Hrvatske. Pristupljeno 26. ožujka 2019. https://www.min-kulture.hr/userdocsimages/2018\%20poziv/obrasci/godi\%C5\%A1njak_2019-02-20_023.pdf.

"Izvješće o analizi trenutnog stanja, Ernst \& Young Savjetovanje d.o.o., ožujak 2018. godine." Ministarstvo kulture Republike Hrvatske. Pristupljeno 2. svibnja 2019. https://www.min-kulture.hr/default.aspx?id=19948.

"Izvještaj o radu Hrvatskoga državnog arhiva u 2016. godini, Zagreb, veljača 2017." Hrvatski državni arhiv. Pristupljeno 25. ožujka 2019. http://www. arhiv.hr/Portals/0/Dokumenti/Planovi\%20i\%20izvje\%C5\%A1\%C4\%87a/ Izvje \%C5\%A1\%C4\%87e\%20o\%20radu \%20HDA\%20u\%202016.\%20 godini.pdf?ver=2017-03-23-092024-000.

"Javni pozivi." Ministarstvo kulture Republike Hrvatske. Pristupljeno 4. travnja 2019. https://www.min-kulture.hr/default.aspx?id=68.

"Kreativna Europa: Vijeće postiglo dogovor o stajalištu u vezi s programom za razdoblje 2021. - 2027." Europsko vijece, Vijeće Europske unije. Pristupljeno 2. svibnja 2019. https://www.consilium.europa.eu/hr/press/press-releases/ 2018/12/20/creative-europe-council-agrees-its-position-on-the-programme-for2021-2027/.

"National Archives of Australia Corporate Plan 2018-19 to 2021-22." National Archives of Australia. Pristupljeno 2. svibnja 2019. http://www.naa.gov.au/ about-us/organisation/accountability/corporate-plan/2018-19-to-2021-22.aspx.

"Odobreni programi ustanova u nadležnosti Ministarstva kulture u 2019. godini." Ministarstvo kulture Republike Hrvatske. Pristupljeno 13. ožujka 2019. https://www.min-kulture.hr/default.aspx?id=21799.

"Operativni program Konkurentnost i kohezija 2014. - 2020., Hrvatski prijevod s engleskog, Zagreb, studeni 2018." Europski strukturni i investicijski fondovi. Pristupljeno 2. svibnja 2019. https://strukturnifondovi.hr/wp-content/ uploads/2019/02/OPKK_070219.pdf.

“Plan rada za 2019. godinu, Bjelovar, srpanj 2018.” Državni arhiv u Bjelovaru. Pristupljeno 28. ožujka 2019. http://www.dabj.hr/dok/Plan\%20rada\%20 u\%202019.\%20godini.pdf. 
“Program Digitalna Europa za razdoblje 2021.-2027.” Europski parlament. Pristupljeno 2. svibnja 2019. http://www.europarl.europa.eu/doceo/document/TA-8-2019-0403_HR.html\#title2.

"Program Europske unije - Kreativna Europa." Ministarstvo kulture Republike Hrvatske. Pristupljeno 2. svibnja 2019. https://www.min-kulture.hr/ced/.

"Sažetak 17. sjednice Hrvatskog arhivskog vijeća održane 4. svibnja 2017. u Ministarstvu kulture, Zagreb, Runjaninova 2." Ministarstvo kulture Republike Hrvatske. Pristupljeno 14. ožujka 2019. https://www.min-kulture.hr/default. aspx?id=365.

"Sažetak 22. sjednice Hrvatskog arhivskog vijeća održane 12. lipnja 2018. u Ministarstvu kulture, Zagreb, Runjaninova 2." Ministarstvo kulture Republike Hrvatske. Pristupljeno 12. ožujka 2019. https://www.min-kulture.hr/default. aspx?id $=365$.

"Sažetak Konstituirajuće sjednice Hrvatskog arhivskog vijeća održane 10. prosinca 2018. u Ministarstvu kulture, Zagreb, Runjaninova 2.” Ministarstvo kulture Republike Hrvatske. Pristupljeno 12. ožujka 2019. https://www.min-kulture. $\mathrm{hr} /$ default.aspx?id=365.

"Smjernice za vrednovanje arhivskih programa." Ministarstvo kulture Republike Hrvatske. Pristupljeno 14. ožujka 2019. https://www.min-kulture.hr/ default.aspx?id=18810.

"Statut Hrvatskog memorijalno-dokumentacijskog centra Domovinskog rata, Zagreb, 2005.” Hrvatski memorijalno-dokumentacijski centar Domovinskoga rata. Pristupljeno 14. ožujka 2019. https://centardomovinskograta.hr/wp-content/uploads/2013/05/Statut.pdf.

"Započeo rad na analitičkom izvještaju o hrvatskoj kulturnoj politici." Ministarstvo kulture Republike Hrvatske. Pristupljeno 13. ožujka 2019. https:// www.min-kulture.hr/novost/default.aspx?id=21895.

Almeda, Pere, Albert Sagarra, Marc Tataret. "Public spending on culture in Europe 2007-2015." European Parliament. Pristupljeno 2. svibnja 2019. http: //www.europarl.europa.eu/cmsdata/139228/ALMEDA_Public\%20spending\% 20on\%20culture\%202007-2015\%20-\%2021F\%20-\%20EP\%20-Cuture\%20 Commission\%2021\%20FEB.pdf.

Antolović, Jadran. Menadžment u kulturi. Zagreb: Hadrian, 2009.

Bestvina Bukvić, Ivana, Marija Mihaljević, Ivana Tokić. "Kulturna politika i utjecaj zakonskog okvira na financiranje kazališta." Pravni vjesnik: časopis za pravne i društvene znanosti pravnog fakulteta Sveučilišta J. J. Strossmayera u Osijeku 31, br. 3-4 (2015): str. 147-166. 
Bukvić, Nenad. "Arhivska služba i arhivsko zakonodavstvo u funkciji zaštite gradiva muzejskih ustanova." Arhivski vjesnik 57 (2014): str. 71-111.

Čopič, Vesna, Péter Inkei, Anita Kangas, Andrej Srakar. “Trends in Public Funding for Culture in the EU (EENC Report, August 2013, Revised July 2014)." European Expert Network on Culture (EENC). Pristupljeno 2. svibnja 2019. http://www.interarts.net/descargas/interarts2573.pdf.

Ćosić, Stjepan, Vlatka Lemić. "Problemi arhivske službe u Hrvatskoj." U Arhivska služba na pragu pristupa Hrvatske Europskoj uniji: 41. savjetovanje, 11. - 13. listopada 2006., Karlovac, Hrvatska, ur. Deana Kovačec, str. 5-12. Zagreb: Hrvatsko arhivističko društvo, 2007.

Ćosić, Stjepan, Vlatka Lemić. "Problemi arhivske službe u Hrvatskoj." Arhivski vjesnik 51 (2008): str. 9-24.

Ćosić, Stjepan, Vlatka Lemić. "Rad arhiva u uvjetima suprotstavljenih utjecaja: država-društvo-korisnici." U Izlaganja s 2. kongresa hrvatskih arhivista (elektronička grada): arhivi i društvo - izazovi suvremenog doba / Drugi kongres hrvatskih arhivista, Dubrovnik, listopad 2005., ur. Ivana Prgin, str. 1-8. Zagreb: Hrvatsko arhivističko društvo, 2005.

Ćosić, Stjepan, Vlatka Lemić. "Rad arhiva u uvjetima suprotstavljenih utjecaja: država - društvo - korisnici." Arhivski vjesnik 49 (2006): str. 7-19. arhiv, 2010.

Ivanović, Jozo. Priručnik iz arhivistike: I. dio. Zagreb: Hrvatski državni

Karajić, Kristijan. "Menadžment arhivskih ustanova i programa." Hrvatska $i$ komparativna javna uprava: ćasopis za teoriju i praksu javne uprave 16, br. 2 (2016): str. 325-326.

Mondekar, Daniel. "Javne politike na razini Europske unije za financijsku perspektivu 2021. - 2027. godine: izazovi, obveze i prilike." EU-Projekti.info. Pristupljeno 2. svibnja 2019. https://www.eu-projekti.info/eu/wp-content/ uploads/2019/02/4_Daniel-Mondekar.pdf.

Prgin, Ivana. "Strateško planiranje i arhivska služba - pozicija i utjecaji." U Arhivi u Hrvatskoj - (retro)perspektiva: 5. kongres hrvatskih arhivista, 24. - 27. listopada 2017., Zadar, ur. Silvija Babić, str. 23-35. Zagreb: Hrvatsko arhivističko društvo, 2017.

Suljagić, Boris. "5. kongres hrvatskih arhivista Arhivi u Hrvatskoj (retro)perspektiva, Hrvatsko arhivističko društvo - Državni arhiv u Zadru. Zadar, 24. - 27. listopada 2017.” Arhivski vjesnik 61 (2018): str. 283-300.

Šugar-Glavaš, Irma. "Financiranje kulture i umjetnosti u Republici Hrvatskoj." Završni rad, Sveučilište Jurja Dobrile u Puli, 2018. Pristupljeno 25. ožujka 2019. https://repozitorij.unipu.hr/islandora/object/unipu:2443/preview. 
Summary

\section{STATE ARCHIVES FINANCING WITHIN PROGRAMMES OF PUBLIC NEEDS IN THE CULTURAL PORTFOLIO OF THE REPUBLIC OF CROATIA}

The article presents the results of state archives financing within programmes of public needs in the cultural portfolio of the Republic of Croatia during the last ten-year period. It is a contribution to the issue of state archives financing in general, which is usually listed among key factors (with spatial and human resources) that determine and condition the position of contemporary archival service in Croatia. The results are systemised in the form of graphs and tables. They are interpreted in the wider context of trends in the change of the Ministry of Culture's proportion in the total state budget and investments in programmes of other cultural services. Inter alia, the results demonstrate which activities, to what extent and in which continuity (short-term, long-term) were in focus of state archives in Croatia, as well as how they corresponded with their core tasks. Together with an analysis of the total amount of appropriations, such data are also one of the indicators of state's attitude towards archival service. The analysis shows that in the period 2010-2018, within public calls for financing programmes of public needs in culture, the Ministry of Culture of the Republic of Croatia approved to state archives 1209 programmes in six categories: archives, international cultural cooperation, computerisation, digitisation, investment aid and preservation of immovable cultural goods. The total amount of appropriations for archival programmes was around 87,8 million HRK, which is 5,87\% of total amount of appropriations provided for all programmes within those six categories. In the comparison with the average annual appropriations from the Ministry of Culture's budget in all cultural services and their programmes, the average annual appropriations in the programmes of state archives were 3,43\%. They depended on the Ministry of Culture's proportion in the total annual state budget in that period. Analysis also demonstrates that three largest users of appropriations were the Croatian State Archives (32,05\%), the State Archives in Dubrovnik (18,36\%) and the State Archives in Zagreb (6,16\%). All other state archives achieved individual shares less than $5 \%$. Such data illustrates disparities between state archives in the number, but also in the variety of applied programmes. Such disparities are the result of specific possibilities of each state archives (such as spatial and human resources), but also the consequence of the absence of long-term planning and development strategies for the archival service in Croatia in general. Such situation should be improved by the National Archival Service Development Plan, adoption of which by the Government of the Republic of Croatia is intended in the new Law on Archives and Archival Institutions (Official Gazette of the Republic of Croatia 61/2018). Besides appropriations from the national budget within described programmes of public needs in 
culture, state archives in Croatia are in front of the challenge to improve financing from other sources. The potential for such improvement is a more active approach to the use of the EU funds, i.e. better positioning of the archival and other cultural services in the EU multiannual financial framework (MFF) for the 2021-2027 period. Also, the results and services developed within archival programmes should be usable as new resources, i.e. potential sources of new income.

Keywords: archives; archival programmes; archival service; financing; cultural services; cultural policy; programmes of public needs in cultural portfolio; Ministry of Culture 